\title{
Application of Weather Research and Forecasting Model with Chemistry (WRF/Chem) over Northern China: Sensitivity Study, Comparative Evaluation, and Policy Implications
}

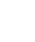

Litao Wang ${ }^{1,2, *}$, Yang Zhang ${ }^{2,3}$, Kai Wang ${ }^{2}$, Bo Zheng ${ }^{4}$, and Qiang Zhang ${ }^{4}$, and Wei 6 Wei $^{5}$

${ }^{1}$ Department of Environmental Engineering, Hebei University of Engineering, Handan, Hebei 8 056038, China

${ }^{2}$ Department of Marine, Earth and Atmospheric Science, North Carolina State University, Raleigh, NC 27695, USA

${ }^{3}$ State Key Joint Laboratory of Environment Simulation and Pollution Control, School of Environment, Tsinghua University, Beijing 100084, China

${ }^{4}$ Center for Earth System Science, Tsinghua University, Beijing100084, China

${ }^{5}$ Department of Environmental Science, Beijing University of Technology, Beijing 100124, China

*Corresponding author: Tel: 86-310-8579208; email: wanglitao@ hebeu.edu.cn

\section{Abstract}

An extremely severe and persistent haze event occurred over the middle and eastern China in January 2013, with the record-breaking high concentrations of fine particulate matter $\left(\mathrm{PM}_{2.5}\right)$. In this study, an online-coupled meteorology-air quality model, the Weather Research and Forecasting Model with Chemistry (WRF/Chem), is applied to simulate this 
pollution episode over East Asia and northern China at 36- and 12-km grid resolutions. A number of simulations are conducted to examine the sensitivities of the model predictions to various physical schemes. The results show that all simulations give similar predictions for temperature, wind speed, wind direction, and humidity, but large variations exist in the prediction for precipitation. The concentrations of $\mathrm{PM}_{2.5}$, particulate matter with aerodynamic diameter of $10 \mu \mathrm{m}$ or less $\left(\mathrm{PM}_{10}\right)$, sulfur dioxide $\left(\mathrm{SO}_{2}\right)$, and nitrogen dioxide $\left(\mathrm{NO}_{2}\right)$ are overpredicted partially due to the lack of wet scavenging by the chemistry-aerosol option with the 1999 version of the Statewide Air Pollution Research Center (SAPRC-99) mechanism with the Model for Simulating Aerosol Interactions and Chemistry (MOSAIC) and the Volatility Basis Set (VBS) for secondary organic aerosol formation. The optimal set of configurations with the best performance is the simulation with the Gorddard shortwave and RRTM longwave radiation schemes, the Purdue Lin microphysics scheme, the KainFritsch cumulus scheme, and a nudging coefficient of $1 \times 10^{-5}$ for water vapor mixing ratio. The emission sensitivity simulations show that the $\mathrm{PM}_{2.5}$ concentrations are most sensitive to nitrogen oxide $\left(\mathrm{NO}_{\mathrm{x}}\right)$ and $\mathrm{SO}_{2}$ emissions in northern China, but to $\mathrm{NO}_{\mathrm{x}}$ and ammonia $\left(\mathrm{NH}_{3}\right)$ emissions in southern China. $30 \% \mathrm{NO}_{\mathrm{x}}$ emission reductions may result in an increase in $\mathrm{PM}_{2.5}$ concentrations in northern China because of the $\mathrm{NH}_{3}$-rich and volatile organic compound (VOC) limited conditions over this area. VOC emission reductions will lead to a decrease in $\mathrm{PM}_{2.5}$ concentrations in eastern China. However, $30 \%$ reductions in the emissions of $\mathrm{SO}_{2}, \mathrm{NO}_{\mathrm{x}}, \mathrm{NH}_{3}$, and VOC, individually or collectively, are insufficient to effectively mitigate the severe pollution over northern China. More aggressive emission controls, which needs to be identified in further studies, are needed in this area to reach the objective of $25 \%$ $\mathrm{PM}_{2.5}$ concentration reduction in 2017 proposed in the Action Plan for Air Pollution Prevention and Control by the State Concil in 2013. 
47 Keywords: WRF/Chem; $\mathrm{PM}_{2.5}$; Regional Haze; Northern China; Comparative evaluation; Sensitivity study

\section{Introduction}

Since January 2013, very frequent and severe haze events occurred over central and eastern China, with the record-breaking high concentrations of fine particulate matter $\left(\mathrm{PM}_{2.5}\right)$ in many cities. Haze has emerged as the most urgent air pollution problem that needs to be addressed in China, more than other existing issues, e.g., photochemical pollution or acid rain. The extremely severe pollution over northern China that covers Beijing-Tianjin-Hebei area (BTH), Shanxi, Henan, and Shandong, has raised widespread public concerns. According to the monthly report publicized by the Ministry of Environmental Protection (MEP) on the top ten polluted cities in China, seven of the nine top polluted cities are within the BTH area (http://www.mep.gov.cn/zhxx/xwfb/). There is an urgent need of understanding the sources and formation mechanisms of the severe haze occurred over this area.

The pollution characteristics and source apportionment over China using 3-D air quality models have been increasingly studied in the past few decades. For example, many studies have been performed to support the policy-making for the 2008 Beijing Olympics and the National Five Year Plan (FYP) using the Community Multiscale Air Quality Model (CMAQ) system (Streets et al., 2007; Chen et al., 2007, 2008; Wang et al., 2008, 2009, 2011; Fu et al., 2009; Zhou et al., 2010, 2012; Xing et al., 2011; Gao and Zhang, 2012; Li et al., 2013; Zhao et al., 2013). However, all those studies used an offline-coupled meteorology and air quality model system, i.e., the meteorological model is run separately from the air quality model to provide the meteorological fields (Zhang, 2008; Zhang et al., 2012a). It does not simulate the feedbacks of chemistry to meteorology, such as the aerosol feedbacks to radiation and 
photolysis, which may be very important during severe pollution periods with high aerosol loading (J. D. Wang et al., 2014). January 2013 has been reported as the haziest month in the past 60 years in Beijing (Lu et al., 2013), and the haziest month since this century in northern

China (L. T. Wang et al., 2014). This month is representative for understanding the severe haze and $\mathrm{PM}_{2.5}$ pollution episodes frequently occurred in recent years over northern China.

Several recent studies focus on this month in terms of the pollution characteristics, formation mechanism, chemical and physical processes, and source apportionment (Ji et al., 2014; Jiang et al., 2014; L. T. Wang et al., 2014; J. D. Wang et al., 2014; Zheng et al., 2014; Y. S. Wang et al., 2014). The results of J. D. Wang et al. (2014), using the coupled Weather Research and Forecasting (WRF)-CMAQ system, shows that during that month the aerosol-meteorology feedbacks can lead to a maximum 53\% reduction in incoming radiation and as high as $140 \mu \mathrm{g}$ $\mathrm{m}^{-3}$ increase in $\mathrm{PM}_{2.5}$ concentrations on daily average in Beijing. It is therefore necessary to apply the online-coupled meteorology-air quality model to simulate the extremely severe haze episodes over this area and understand the underlying formation mechanisms.

The Weather Research and Forecasting Model with Chemistry (WRF/Chem) (Grell et al., 2005; Fast et al., 2006) is one of the most advanced online-coupled 3-D air quality models, which has been increasingly applied at global, continental, and regional scales over North America, Europe, and Asia in recent years (Misenis and Zhang, 2010; Zhang et al., 2010a, 2012b, c, 2013; Tuccella et al., 2012; Situ et al., 2013; Tie et al., 2009, 2013; Chen et al., 2013; Wu et al., 2013). However, studies over the North China Plain (NCP) are very limited (Han et al., 2008; An et al., 2013; Yan, 2013) and none of them included sensitivity studies of the chemical or physical configurations which are important to the model predictions

93 (Misenis and Zhang, 2010; Zhang et al., 2012b). Therefore, in this study, WRF/Chem 
applied over East Asia and northern China at 36- and 12-km grid resolutions, respectively, for the extremely polluted period of January 2013, and a series of sensitivity simulations are conducted to evaluate the model performances using different physical schemes and explore relevant emission control implications. The objectives of this study are to (1) examine the sensitivities of the model predictions for both meteorology and chemical species to various

100 physical schemes available in WRF/Chem; (2) identify an optimal set of configurations that has the best performance on both meteorology and air quality over northern China; (3) quantify the $\mathrm{PM}_{2.5}$ sensitivities to the reductions of emissions of major pollutants, to support the policy-making in air pollution control over this area.

The paper is organized as follows: Section 2 describes the model configurations for all simulations, and evaluation database and protocols. Section 3 presents the results from a comparative evaluation on air quality, the best set of configurations and its performance (the meteorology evaluations are in the supplementary material). Section 4 examines the sensitivities of particulate matter (PM) predictions to precursor emission reductions and implications to emission control strategies. Section 5 summarizes the major findings and

110 limitations of this work.

\section{Model description and evaluation methodology}

\section{$113 \quad 2.1$ Model configurations and simulation design}

114 In this study, WRF/Chem simulations are performed for the period of January 2013, 115 because the regional haze events during this period represent the most severe episode with the

116 highest $\mathrm{PM}_{2.5}$ concentrations in China since 2001. A spin-up period of seven days (December $11725-31,2012$ ) is used to minimize the influence of the initial conditions. The model inputs and 
118 configurations used in this study are shown in Table 1a. As shown in Table 1b, a total of 11

119 sensitivity simulations are conducted using various combinations of physical schemes for

120 East Asia with a grid resolution of $36 \times 36 \mathrm{~km}$ (Domain 1, see Figure 1). One set of

121 configurations with the best model performance is chosen to perform nested simulations

122 using one-way nesting over northern China that encompasses Beijing, Tianjin, and four

123 provinces including Hebei, Henan, Shandong, and Shanxi at a $12 \times 12 \mathrm{~km}$ grid resolution

124 (Domain 2). Six sensitivity simulations in which the emissions of sulfur dioxide $\left(\mathrm{SO}_{2}\right)$,

125 nitrogen oxide $\left(\mathrm{NO}_{\mathrm{x}}\right)$, ammonia $\left(\mathrm{NH}_{3}\right)$, and volatile organic compounds (VOCs) are reduced

126 by $30 \%$ individually and collectively, are then conducted over Domain 1 to examine the

$127 \mathrm{PM}_{2.5}$ sensitivities to precursor emissions. The vertical resolutions in all simulations are 23

128 layers from the surface to the tropopause. The corresponding sigma levels are 1.000, 0.995,

$1290.988,0.980,0.970,0.956,0.938,0.916,0.893,0.868,0.839,0.808,0.777,0.744,0.702$,

$130 \quad 0.648,0.582,0.500,0.400,0.300,0.200,0.120,0.052$, and 0.000 .

131 The accuracy of emissions is key to the reliability of the model predictions. In this 132 study, the Multi-resolution Emission Inventory for China (MEIC) (He, 2012; Li et al., 2014)

133 for the base year 2010 is used, following the study of L. T. Wang et al. (2014). The MEIC 134 inventory, developed by Tsinghua University, calculates all the anthropogenic emissions of 135 eight species, including $\mathrm{SO}_{2}, \mathrm{NO}_{\mathrm{x}}$, carbon monoxide $(\mathrm{CO})$, non-methane volatile organic 136 compounds (NMVOCs), $\mathrm{NH}_{3}$, carbon dioxide $\left(\mathrm{CO}_{2}\right), \mathrm{PM}_{10}$, and $\mathrm{PM}_{2.5}$ in China for the years 1371990 to 2010 . Note the MEIC inventory not only contains the emission data for the above 138 eight species, but also for the speciated chemical species of VOCs and PM for SAPRC, CB05 139 and RADM mechanisms ( $\mathrm{Li}$ et al., 2014). The SAPRC99-speciated VOCs inventories are 140 used in this study. L. T. Wang et al. (2014) demonstrated that the MEIC inventory provides 141 reasonable estimations of the total emissions from cities, but may be subject to uncertainties 
142 in the spatial allocations of those emissions into fine grid resolutions. Another uncertainty

143 exists in the difference between the emission base year (2010) and simulation period (January

144 2013). The total anthropogenic emissions may have been underestimated due to the economic 145 increase during 2010-2013 (The national GDP increased 9.3\% and 7.8\% in 2011 and 2012, 146 respectively (NBS, 2013)). The Model of Emissions of Gases and Aerosols from Nature 147 (MEGAN) version 2 (Guenther et al., 2006) is used for online calculation of the biogenic 148 emissions. Dust emissions are estimated online using the Goddard Chemistry Aerosol 149 Radiation and Transport (GOCART) model (Ginoux et al., 2001). The sea-salt emissions are 150 calculated using the method by Gong (2003).

The meteorological initial (IC) and boundary conditions (BC) are based on the National

152 Center for Environmental Prediction (NCEP) Final Analysis (FNL) reanalysis datasets. 153 Analysis nudging is applied for wind in and above PBL, and for temperature and water vapor 154 mixing ratio (Q) above PBL, using the NCEP surface and upper air observation dataset 155 (http://dss.ucar.edu/datasets/ds351.0/; http://dss.ucar.edu/datasets/ds461.0). The default 156 chemical profiles in WRF/Chem are used as the chemical IC and BC for the domain 1, and 157 those for the domain 2 are nested down from the output of domain 1. mechanism (Cater, 1990, 2000) is chosen as the gas-phase chemical mechanism in this work,

160 which is demonstrated by Lin et al. (2009) of better performance than the Carbon Bond 4 161 (CB4) over East Aisa and gives satisfactory results over northern China for the haze episode 162 simulation described in L. T. Wang et al. (2014). The aerosol module is the Model for 163 Simulating Aerosol Interactions and Chemistry (MOSAIC) that uses 4 volatility bins with the 164 Volatility Basis Set (VBS) for organic aerosol evolution (Zaveri et al., 2008; Shrivastava et 165 al., 2011). The Madronich Fast Troposphere Ultraviolet Visible (F-TUV) photolysis scheme 
is applied for photolytic rate calculation. The urban canopy model (Kusaka and Kimura, 2004; Ikeda and Kusaka, 2010) is used for urban surface scheme.

The baseline configurations include the RRTMG shortwave and longwave radiation schemes (Iacono et al., 2008), the Noah Land Surface Model (Chen and Dudhia, 2001; Ek et 170 al., 2003), the Monin-Obukhov surface layer model (Monin and Obukhov, 1954; Janjic, 2001), the Yonsei University (YSU) Planetary Boundary Layer (PBL) scheme (Hong et al., 2006), the Grell 3D ensemble cumulus parameterization (Grell and Devenyi, 2002), and the Morrison double-moment microphysics scheme (Morrison et al., 2009). The RRTMG radiation schemes, the Grell 3D ensemble cumulus parameterization, and the Morrison double-moment microphysics scheme were recently implemented in WRF/Chem to provide advanced treatments of relevant processes. The rest of physics options have been applied extensively in past studies (e.g., Grell et al., 2005; Zhang et al., 2010a, 2012a,b, 2013). The combination of the above physics options is therefore selected as the starting point to systematically test various physics schemes and identify an optimal set of physics schemes to support WRF/Chem modeling. The sensitivity simulations are designed to use the same set

181 of aforementioned configurations but each with an alternative physical option or a combination of several alternative options including shortwave and longwave radiation schemes, land surface and surface layer models, a PBL scheme, a cumulus parameterization, and a microphysics scheme. As shown in Table $1 \mathrm{~b}$, a total 10 sensitivity simulations for

185 physical schemes and 6 simulations for emission sensitivities are performed in this study.

186 First, the shortwave and longwave radiation schemes, microphysics scheme, and cumulus 187 parameterization are changed one at one time to assess the changes in model performance. 188 The schemes with better performance are then combined in several simulations to identify the best set of configurations. The nudging coefficient for Q, and the kfeta_trigger option (NCAR, 
190 2013) in Kain-Fritsch cumulus scheme (Kain, 2004) are changed as well to improve the 191 model predictions for precipitation. The Pleim-Xiu land surface (Pleim and Xiu, 1995; Xiu 192 and Pleim, 2001) and surface layer (Pleim, 2006) schemes are only applied in WRF/Chem

193 version 3.5.1 because those schemes are not fully linked in the version 3.5 and result in 194 unrealistically high concentrations for all pollutants, e.g., the monthly average concentrations 195 of CO over whole the BTH area are predicted as high as above $16 \mathrm{ppm}$ whereas the observed 196 CO concentrations are in the range of $0.4-5.0 \mathrm{ppm}$. The set of configurations are considered 197 as the best when it meets the model evaluation criterias and gives the best performance 198 statistics among all the simulations, in both meteorology and chemical predictions. The set of 199 configurations with the best performance is then used in the emission sensitivity simulations.

200 In the sensitivity study, the emissions of $\mathrm{SO}_{2}, \mathrm{NO}_{\mathrm{x}}, \mathrm{NH}_{3}$, and $\mathrm{VOC}$ are reduced by $30 \%$, 201 individually and collectively, i.e., $\mathrm{SO}_{2} / \mathrm{NO}_{\mathrm{x}} / \mathrm{NH}_{3}$ and $\mathrm{SO}_{2} / \mathrm{NO}_{\mathrm{x}} / \mathrm{NH}_{3} / \mathrm{VOC}$, to quantify the 202 responses of the $\mathrm{PM}_{2.5}$ concentrations to provide scientific information in support of future 203 emission control policy-making. 30\% reduction in emissions is chosen for several reasons. 204 First, the Action Plan for Air Pollution Prevention and Control released by the State Council 205 on September 10, 2013 calls for a reduction of the $\mathrm{PM}_{2.5}$ concentrations over Beijing-Tianjin206 Hebei area by $25 \%$ in 2017. In the Action Plan for Air Pollution Prevention and Control in 207 Hebei Province published by Hebei Province following the National Action Plan, the 208 attainment goal of $\mathrm{PM}_{2.5}$ concentrations in Hebei cities is set to be a reduction of $25-33 \%$ in 209 2017. Given those attainment goals at both national and province levels, the use of $30 \%$ 210 emission reductions in the sensitivity represents the first attempt before a larger reduction can 211 be justified to reach the attainment goals in a short-term, i.e., 3-5 years. 


\subsection{Evaluation database and protocols}

The observational data used for model evaluation in this study are same to those used in

215 L. T. Wang et al. (2014) but for the period of Janurary 1-31, 2013 (see Table 1, Wang et al.,

216 2014). The meteorological data used in this study are obtained from the National Climate

217 Data Center (NCDC) integrated surface database. The evaluations are performed for the five

218 major parameters: temperature at 2-m (T2), water vapor mixing ratio at 2-m (Q2), wind speed

219 at 10-m (WS10), wind direction at 10-m (WD10), and daily precipitation. Data at every 1- or

220 3-hour (most at 3-hour) at a total of 371 sites within our domains are used in the evaluation.

As in the study of L. T. Wang et al. (2014), two datasets of chemical concentrations are

used. The first one is the real-time database from the China National Environmental Monitoring Center (CNEMC), which began to be released since January 2013 and includes the real-time hourly concentrations of $\mathrm{SO}_{2}, \mathrm{NO}_{2}, \mathrm{CO}$, ozone $\left(\mathrm{O}_{3}\right), \mathrm{PM}_{2.5}$, and $\mathrm{PM}_{10}$ at 496 national monitoring stations in 74 major cities in China. The 74 cities include all the capital cities of each province, municipalities, and all the cities within the Beijing-Tianjin-Hebei area (BTH), the Yangtze River Delta (YRD), and the Pearl River Delta (PRD) (http://113.108.142.147:20035/emcpublish/). As mentioned in L. T. Wang et al. (2014), CNEMC provides a much better database for model evaluation than the previous Air Pollution Index (API) database which only provides a daily index for the key pollutant on urban average for each city (Streets et al., 2007; Wang et al., 2008; Fu et al., 2009). However the main difficulty in using CNEMC is the inaccessibility of the historic data of more than 24-hr ago. This is the reason that in our study the observations for the period of January 1-13 are unavailable for the model evaluation. The second data source is the observations at a site located in the Hebei University of Engineering (refer to as HEBEU) measured by the lead author's group since July 2012 (Wei et al., 2014). More detailed descriptions of the 
characteristics of the site and measurement method can be found in Wei et al. (2014). The observed hourly $\mathrm{PM}_{2.5}, \mathrm{PM}_{10}, \mathrm{SO}_{2}, \mathrm{NO}_{2}$, and $\mathrm{CO}$ concentrations at this site are used in the model evaluation for the whole month of January 2013.

The meteorological evaluation is performed in terms of domainwide overall statistics.

241 The statistical measures calculated include the Mean Bias (MB), the Root Mean Square Error 242 (RMSE), the Normalized Mean Bias (NMB), and the Normalized Mean Error (NME), which are defined in Zhang et al. (2006). The criteria proposed by Emery et al. (2001) and Tesche et al. (2001) are used to judge meteorological performance. According to Emery et al. (2001) and Tesche et al. (2001), a satisfactory model performance should have $\mathrm{MB} \leq \pm 0.5 \mathrm{~K}$ for T2, $\mathrm{MB} \leq \pm 1 \mathrm{~g} \mathrm{~kg}^{-1}$ for $\mathrm{Q} 2, \mathrm{MB} \leq \pm 0.5 \mathrm{~m} \mathrm{~s}^{-1}$ for $\mathrm{WS10}$, and MB $\leq \pm 10^{\circ}$ for WD10. The chemical evaluation is performed in terms of the overall statistics, and spatial distributions by comparing the simulated and observed concentration distributions and corresponding NMBs. In addition to NMB and NME, the Mean Fractional Bias (MFB) and the Mean Fractional Error (MFE) are analyzed, following the guidance by U. S. Environmental Protection Agency (U. S. EPA, 2007). They are also defined in Zhang et al. (2006). Boylan and Russell (2006) suggested that a model performance goal of MFB $\leq \pm 30 \%$ and MFE $\leq 50 \%$ and the model performance criteria of $\mathrm{MFB} \leq \pm 60 \%$ and $\mathrm{MFE} \leq 75 \%$ for $\mathrm{PM}$ modeling, which are used as criteria for model performance for PM and gaseous species. In addition, time series of meterological and chemical variables at several representative sites in both domains are analyzed to assess the model performance in reproducing the temporal variations of meteorology and air quality. The evaluation of meteorology is presented in the supplementary material, and those for chemical species are in the Section 3 below. 


\section{Comparative evaluation of model performance}

261

262

263

264

265

266

267

268

269

270

271

272

273

274

275

276

277

278

279

280

281

282

283

\subsection{Evaluation over East Asia}

As showns in Tables $\mathrm{S} 1$ and S2, the simulations of PX_RAD_MP_KF_Q_351 and RAD_MP_KF_Q give the best meteorological predictions among all the 11 simulations. Table 2 summarizes the domainwide statistics for chemical species, i.e., $\mathrm{PM}_{2.5}, \mathrm{PM}_{10}, \mathrm{SO}_{2}$, $\mathrm{NO}_{2}$, and $\mathrm{CO}$ over Domain 1 at the 36-km grid resolution. In general, the model overpredicts the concentrations of those pollutants, i.e., the concentrations of $\mathrm{PM}_{2.5}$ and $\mathrm{PM}_{10}$ are overpredicted by the 11 simulations by $28-48 \%$ and $0-8 \%$, respectively, and those of $\mathrm{SO}_{2}$, $\mathrm{NO}_{2}$, and $\mathrm{CO}$ are overpredicted by $33-91 \%, 9-27 \%$, and $1-12 \%$, respectively. One of the major reasons is the lack of wet scavenging scheme for the SAPRC-99 and MOSAIC-VBS option in WRF/Chem 3.5 and 3.5.1 (Peckham et al., 2013). Saide et al. (2012) evaluated the influence of wet deposition to atmospheric concentrations of gaseous and aerosol species by simulations with/without wet scavenging process using WRF/Chem. They found that significant differences existed in $\mathrm{SO}_{2}$ and aerosol concentrations when the wet deposition process was turn off. Therefore, the uncertainties introduced by the lack of wet scavenging should be considered in model evaluation, as well as distinguishing them from the uncertainties from the emission inventory. The uncertainties of the MEIC emission inventory are estimated to be smaller or same to the INTEX-B emission inventory, which are $\pm 12 \%$ for $\mathrm{SO}_{2}, \pm 31 \%$ for $\mathrm{NO}_{\mathrm{x}}, \pm 68 \%$ for NMVOCs, $\pm 70 \%$ for $\mathrm{CO}, \pm 132 \%$ for $\mathrm{PM}_{10}, \pm 130 \%$ for $\mathrm{PM}_{2.5}$ for China (Q. Zhang et al., 2009; private communication, Qiang Zhang, Tsinghua University, China, September, 2014). Although large uncertainties may exist in the primary PM emission inventory, the secondary inorganic and organic aerosols, generated from the gaseous precursors which have much smaller uncertainties, are believed to be the driving factors during this severe polluted month (Huang et al., 2014; Zheng et al., 2014). The modeling 
results over the same domains for the same period using the exactly same inventory and same chemical mechanism but with the MM5-CMAQ system that includes wet scavenging process (L. T. Wang et al., 2014) showed that $\mathrm{PM}_{2.5}$ are slightly underpredicted over Domain 1 (with an NMB of $-14.6 \%$ ) and over-estimated over Domain 2 (with an NMB of 19.1\%). These results may imply that the range of the uncertainties introduced by the MEIC inventory, which cannot explain WRF/Chem performance (i.e., the RAD_MP_KP_Q simulation) with the NMB of $31 \%$ for Domain 1 and $45 \%$ for Domain 2 in this work, the lack of wet scavenging is most likely responsible for the overpredictions in $\mathrm{PM}_{2.5}$ concentrations.

As shown in Table 2, the averaged observed $\mathrm{PM}_{2.5}$ concentration over Domain 1 is $137.2 \mu \mathrm{g} \mathrm{m}^{-3}$, and that of the baseline prediction is $201.5 \mu \mathrm{g} \mathrm{m}^{-3}$, with $47 \%$ of overprediction.

294 Changing in the radiation, microphysics and cumulus schemes individually, i.e., RAD, MP, and CU_GD, will result in a slightly better performance $\left(186.6-201.0 \mu \mathrm{g} \mathrm{m}^{-3}\right)$. The combined configurations used in RAD_MP_KF and the reduction in nudging coefficient of Q used in RAD_MP_KF_Q further reduce the overprediction (182.5 and $179.4 \mu \mathrm{g} \mathrm{m}^{-3}$, respectively) and the changing in nudging coefficient of $\mathrm{Q}\left(\mathrm{RAD} \_\mathrm{MP} \_\mathrm{KF} \_\mathrm{Q}\right)$ results in the $\mathrm{PM}_{2.5}$ concentration of $179.4 \mu \mathrm{g} \mathrm{m}^{-3}$. Although there is a large discrepancy on the precipitation predictions between the two simulations ( 0.7 vs. 1.3$)$, the concentrations of $\mathrm{PM}_{2.5}$ are not changed significantly due to the lack of wet scavenging for these options in this version of WRF/Chem. Our study indirectly attests the importance of wet scavenging process to pollutants concentrations, which should be one of the foci and priorities for model improvement for the SAPRC99-MOSAIC/VBS option. While NMBs and NMEs are 28-47\% and 66-78\%, respectively, MFBs are 16-29\% and MFEs are 57-60\% for $\mathrm{PM}_{2.5}$ predictions from all simulations. The performance of $\mathrm{PM}_{2.5}$ predictions by all those simulations is considered to be satisfactory based on the performance criteria of an MFB within $\pm 60 \%$ and 
an MFE within 75\% proposed by Boylan and Russell (2006). Among the 11 simulations, the simulations with the best performance for $\mathrm{PM}_{2.5}$ are PX_RAD_MP_KF_Q_351, PX_RAD_MP_KF_351, and RAD_MP_KF_Q, which have the lowest NMBs, NMEs, MFBs, and MFEs. Compared to $\mathrm{PM}_{2.5}$ performance, the predictions for $\mathrm{PM}_{10}$ show much improved performance statistics with small differences among the 11 simulations. The smaller biases (NMBs of $0-8 \%$ ) in $\mathrm{PM}_{10}$ predictions indicate bias compensation, i.e., the relatively large overpredictions in the $\mathrm{PM}_{2.5}$ concentrations are compensated by large underpredictions in those of $\mathrm{PM}_{2.5-10}$ (e.g., mineral dust).

As for $\mathrm{SO}_{2}$, the observation is $74.8 \mu \mathrm{g} \mathrm{m}^{-3}$ and baseline prediction is $129.4 \mu \mathrm{g} \mathrm{m}^{-3}$, with an NMB of $73 \%$. Changes in radiation and cumulus parameterizations, i.e., RAD, CU_GD, and CU_KF, do not evidently improve the results $\left(124.2-129.9 \mu \mathrm{g} \mathrm{m}^{-3}\right)$, but using a different microphysics scheme from BASE in MP (i.e., the Purdue Lin microphsics scheme), greatly reduces the overprediction $\left(107.9 \mu \mathrm{g} \mathrm{m}^{-3}\right.$, with an NMB of $\left.44 \%\right)$, although the overprediction remains. The simulations of RAD_MP_KF, RAD_MP_KF_Q, and RAD_MP_KF_TRI give slightly better results (99.4-104.3 $\mu \mathrm{g} \mathrm{m}^{-3}$ ). The simulations with the WDM6 microphysics scheme (RAD_WDM6_KF) and the Pleim-Xiu land surface and surface layer schemes (PX_RAD_MP_KF_351 and PX_RAD_MP_KF_Q_351) do not give better predictions for $\mathrm{SO}_{2}$, with NMBs of $61-91 \%$. The simulation RAD_MP_KF_Q gives the best performance for $\mathrm{SO}_{2}$ predictions. The MFBs and MFEs of all the simulations are in the range of 2-28\% and $81-88 \%$, respectively, which are within the criteria of MFB $\leq \pm 60 \%$ and slightly over the criteria of MFE $\leq 75 \%$ proposed by Boylan and Russell (2006). The overpredictions of $\mathrm{NO}_{2}$ are not as significant as those for $\mathrm{SO}_{2}$ with $\mathrm{NMBs}$ of 9-27\%. Similar to $\mathrm{SO}_{2}, \mathrm{NO}_{2}$ predictions are more sensitive to the choice of microphysics schemes. The simulation with the Purdue

331 Lin scheme (MP) performs better than the Morrison double moment used in BASE and the 
332 WDM6 used in RAD_WDM6_KF. In general, the RAD_MP_KF_Q shows the best 333 performance in terms of $\mathrm{NO}_{2}$ predictions with an $\mathrm{NMB}$ of only $9 \%$. The predictions of $\mathrm{CO}$ 334 agree well with observations, with NMBs of $1-12 \%$ of all the simulations. The observed and 335 simulated concentrations of CO by the BASE simulation are 2.3 and $2.5 \mathrm{mg} \mathrm{m}^{-3}$, respectively, 336 with an NMB of $12 \%$. Changing in radiation and microphysics, i.e., RAD and MP, will 337 improve the results (NMBs of 5-7\%), but the alternation in cumulus parameterizations 338 (CU_GD, CU_KF) will not result in a significant improvement (NMBs of 11-12\%). The combined simulations of RAD_MP_KF, RAD_MP_KF_Q, and RAD_MP_KF_TRI further 340 reduce the NMBs to $1-2 \%$. The RAD_MP_KF_Q shows the best performance. The MFBs 341 and MFEs of $\mathrm{NO}_{2}$ and $\mathrm{CO}$ predictions are all within the criteria of MFB $\leq \pm 60 \%$ and $\mathrm{MFE} \leq$ 75\% (Boylan and Russell, 2006).

Among the 11 simulations, the optimal configuration set with the best overall

344 performance in terms of both meteorological and chemical predictions is RAD_MP_KF_Q.

345 Therefore, this configuration is chosen for nested simulations at $12-\mathrm{km}$ and emission 346 sensivity simulations at $36-\mathrm{km}$. Figure 2 presents the overlay of the predicted and observed 347 monthly average concentrations of the four major pollutants and their corresponding NMBs 348 from RAD_MP_KF_Q. The model generally well reproduces the spatial distributions of the 349 four pollutants, especially for $\mathrm{PM}_{10}, \mathrm{NO}_{2}$, and $\mathrm{CO}$. The overprediction of $\mathrm{PM}_{2.5}$ mostly 350 appears in the north and central China, e.g., Shanxi, Henan, southern Hebei, northern Anhui, 351 and the cities along the Yangtze River. The $\mathrm{SO}_{2}$ concentrations over southern Hebei are underpredicted, and the overprediction occurs in the Northeast China, Shanxi, and also the cities along the Yangtze River. The time series of the observed and simulated (RAD_MP_KF_Q) concentrations at the representative cities in Domain 1 are presented in the Section 4 of the supplementary material. 


\subsection{Evaluation over northern China}

The meteorological evaluation for Domain 2 are in Section 2 of the supplementary material. It indicates that the RAD_MP_KF_Q configuration shows the best performance over Domain 2 and the nested simulation at a 12-km grid resolution improves the predictions for temperature and humidity, and performs similarly for other meteorological predictions. The improvements on meteorological predictions of the RAD_MP_KF_Q comparing with the

363 BASE in terms of NMB are summarized in Table 3, for both Domain 1 and 2. In general, the model performances are improved in terms of $\mathrm{T} 2$ and precipitation, not changed for WD10, and slightly declined for Q2 and WS10. The most signicant improvement is for precipitation, with NMBs decreased from $-76 \%$ to $-3 \%$ over Domain 1 (at $36-\mathrm{km}$ grid resolution), and $-82 \%$ to $19 \%$ (at 36-km grid resolution) and 21\% (at 12-km grid resolution) over Domain 2.

The statistics over Domain 2 for chemical variables are shown in Table 4. In general, the model overpredicts the concentrations of all species over the Domain 2 at a 36-km grid resolution, with NMBs of $45-70 \%$ for $\mathrm{PM}_{2.5}, 3-23 \%$ for $\mathrm{PM}_{10}, 32-114 \%$ for $\mathrm{SO}_{2}, 36-61 \%$ for $\mathrm{NO}_{2}$, and $18-74 \%$ for $\mathrm{CO}$. The NMB of RAD_MP_KF_Q for $\mathrm{PM}_{2.5}$ is $50 \%$ at $36-\mathrm{km}$ and reduces to $23 \%$ at $12-\mathrm{km}$. The MFBs and MFEs for $\mathrm{PM}_{2.5}$ predictions from all the $36-\mathrm{km}$ simulations are $23-48 \%$ and $58-64 \%$, respectively, which are still within the threshold for satisfactory performance proposed by the U. S. EPA (2007) and Boylan and Russell (2006). The NMBs for $\mathrm{PM}_{10}$ are much smaller than for $\mathrm{PM}_{2.5}$, indicating that the model underpredicts the concentrations of $\mathrm{PM}_{2.5-10}$. The NMBs of RAD_MP_KF_Q for PM $\mathrm{M}_{10}$ are $9 \%$ at $36-\mathrm{km}$, and $4 \%$ at $12-\mathrm{km}$. As for $\mathrm{SO}_{2}, \mathrm{RAD} \_\mathrm{MP} \_\mathrm{KF} \_\mathrm{Q}$ performs the best among all the simulations at $36-\mathrm{km}$, with an NMB of $32 \%$, an MFB of $22 \%$ (within the criteria of MFB $\leq \pm 60 \%$ ), and 
an MFE of $76 \%$ (slightly over the criteria of MFE $\leq 75 \%$ ), but the NMB at $12-\mathrm{km}$ dramatically increases to $113.4 \%$ (with an MFB of $30 \%$ and an MFE of 93\%). Figure 3 presents the overlay of the simulated and observed monthly average concentrations of $\mathrm{PM}_{2.5}$, $\mathrm{PM}_{10}, \mathrm{SO}_{2}, \mathrm{NO}_{2}$, and $\mathrm{CO}$ at the 36- and 12-km grid resolutions over Domain 2, and the corresponding NMBs. The model generally captures the spatial distributions of $\mathrm{SO}_{2}$ pollution (Figure 3(a-b)). The significant change of NMBs mostly occurrs in Hebei area (Figure 3(c-d)), where the model underpredicts the $\mathrm{SO}_{2}$ concentrations over most of the cities in Hebei area at 36-km, but it shows noticeable overpredictions when nesting to 12-km. Since $\mathrm{SO}_{2}$ is more sensitive to the local source emissions, this change implies that uncertainties exist in the spatial allocations of the emissions into a finer grid resolution. It may overestimate the $\mathrm{SO}_{2}$ emissions in the urban grids if the population density was used as a surrogate to distribute the emissions into a finer grid resolution, as discussed in L. T. Wang et al. (2014). The distribution of NMBs for $\mathrm{NO}_{2}$ and $\mathrm{CO}$ also shows the similar characteristics between predictions at 36- and $12-\mathrm{km}$, despite to a lesser extent comparing to those for $\mathrm{SO}_{2}$. The NMBs, MFBs, and MFEs of $\mathrm{NO}_{2}$ predictions from RAD_MP_KF_Q are 36\%, 27\%, and 55\% at $36-\mathrm{km}$, and $40 \%, 12 \%$, and $64 \%$ at $12-\mathrm{km}$, respectively, and those for $\mathrm{CO}$ are $18 \%, 16 \%$, and $55 \%$ at $36-\mathrm{km}$, and $36 \%, 10 \%$, and $65 \%$ for $12-\mathrm{km}$, respectively. In general, the model gives reasonable predictions and RAD_MP_KF_Q performs the best among all the 36-km

397 simulations over the Domain 2. The nested simulation at $12-\mathrm{km}$ further improves the 398 performances for $\mathrm{PM}_{2.5}$ and $\mathrm{PM}_{10}$ but deterioration occurs for $\mathrm{SO}_{2}, \mathrm{NO}_{2}$, and $\mathrm{CO}$ due partially 399 to the uncertainties in the spatial distribution of the emissions into the fine grid resolution.

400 The summary of model performance improvements of RAD_MP_KF_Q comparing with the 401 BASE in terms of NMB over both Domain 1 and 2 is presented in Table 5. The time series of 
the observed and simulated (RAD_MP_KF_Q) concentrations at the representative cities within Domain 2 are presented in the Section 5 of the supplementary material.

\section{Emission sensitivity and policy implications}

Figure 4 shows the $\mathrm{PM}_{2.5}$ concentrations simulated by the optimal configuration, i.e., RAD_MP_KF_Q, (hereafter BASE_EMIS) and their sensitivities to the emission reductions (by $30 \%$ ) of $\mathrm{SO}_{2}, \mathrm{NO}_{\mathrm{x}}, \mathrm{NH}_{3}$, and VOCs individually and collectively, i.e., emissions of $\mathrm{SO}_{2}$, $\mathrm{NO}_{\mathrm{x}}, \mathrm{NH}_{3}$, and VOCs are reduced by $30 \%$ individually (i.e., the simulations $\mathrm{SO}_{2} \_30, \mathrm{NO}_{\mathrm{x}} \_30$, $\mathrm{NH}_{3} \_30$, and VOCs_30, respectively), those of $\mathrm{SO}_{2}, \mathrm{NO}_{\mathrm{x}}$, and $\mathrm{NH}_{3}$, are reduced

411 simutaneously (i.e., the simulation $\mathrm{SO}_{2} \_\mathrm{NO}_{\mathbf{X}} \_\mathrm{NH}_{3}$ 30), and those of $\mathrm{SO}_{2}, \mathrm{NO}_{\mathbf{x}}, \mathrm{NH}_{3}$, and

412 VOCs are reduced by $30 \%$ simutaneously (i.e., the simulation $\mathrm{SO}_{2} \_\mathrm{NO}_{\mathrm{X} \_} \mathrm{NH}_{3}$ VOCs_30). It

413 should be noted that lack of wet scavenging will extend the lifetime of atmospheric aerosols

414 and soluble gaseous pollutants. The increase of the lifetime of some precursors of $\mathrm{PM}_{2.5}$, e.g., $415 \mathrm{SO}_{2}, \mathrm{NO}_{2}, \mathrm{NH}_{3}$, and VOCs, will results in differences in atmospheric chemistry and thus $\mathrm{PM}_{2.5}$ composition and concentrations (Knote et al., 2013; Garrett. et al., 2006). And extend

417 of $\mathrm{PM}_{2.5}$ lifetime will lead to the changes in radiation, cloud process, etc., in online-coupled 418 simulations. Although it will affect the performance statistics of a single simulation, it will 419 not lead to significant differences in predicted sensitivities, as both the baseline and sensitivity simulations do not include wet scavenging.

As shown in Figure $4 \mathrm{~b}$, the largest reduction in $\mathrm{SO}_{2}$ concentrations due to $30 \%$ reductions in $\mathrm{SO}_{2}$ emissions occurs in the Sichuan Basin, southern Hebei, Hubei, and northern Hunan, at the level of $2-15 \mu \mathrm{g} \mathrm{m} \mathrm{m}^{-3}$, which is about $2.5-10 \%$ of the $\mathrm{PM}_{2.5}$ concentrations predicted by BASE_EMIS. These results show that $30 \%$ reduction of $\mathrm{SO}_{2}$ emissions will not result in significant decreases in $\mathrm{PM}_{2.5}$ concentrations. 
Emission reduction of $\mathrm{NO}_{\mathrm{x}}$ will lead to an notable increase (instead of decrease) in $427 \mathrm{PM}_{2.5}$ concentrations over the NCP, especially southern area of Hebei, Shandong, and 428 northern area of Henan. The increases are 2-25 $\mu \mathrm{g} \mathrm{m}^{-3}$, which are $2.5-8.3 \%$ of the $\mathrm{PM}_{2.5}$ concentrations from BASE_EMIS. This is because the NCP area is under the $\mathrm{NH}_{3}$-rich and 430 VOC-limited conditions which are discussed in Section 6 in the supplementary material.

It should be noted that the observational data of the indicators mentioned in the Section 6 in the supplementay material are not available over China to verify simulated model sensitivity. However, the observations of another indicator, i.e., the ratios of column mass abundance of $\mathrm{HCHO} / \mathrm{NO}_{2}$ (Tonnesen and Dennis, 2000a, b; Y. Zhang et al., 2009, 2010b), can be calculated from the satellite observed column mass concentrations of $\mathrm{HCHO}$ and $\mathrm{NO}_{2}$. Figure 5 compares the simulated and observed tropospheric column mass abundance of $\mathrm{HCHO}$ and $\mathrm{NO}_{2}$, and their ratios. The observed column mass abundances are derived from the Ozone Monitoring Instrument (OMI) on the Aura satellite launched by the National Aeronautics and Space Administration. Both $\mathrm{HCHO}$ and $\mathrm{NO}_{2}$ columns are level-3 monthly averaged retrieval data available to the public, which are then interpolated to the $36-\mathrm{km}$ grid 441 resolution using the bilinear interpolation of the NCAR command language 442 (http://www.ncl.ncar.edu). Figure 5 indicates that the model predictions agree quite well in 443 terms of not only the tropospheric column of $\mathrm{HCHO}$ and $\mathrm{NO}_{2}$, but also their ratios, especially over northern China. The values of $\mathrm{HCHO} / \mathrm{NO}_{2}$ over the $\mathrm{NCP}$ are around 0.5 , which clearly indicates the VOC-limited regime $\left(\mathrm{HCHO} / \mathrm{NO}_{2}<1\right)$. This is also consistent with the studies 446 of Zhang et al. (2009), Liu et al. (2010), and Zhao et al. (2013).

447 Therefore, the reduction of $\mathrm{NO}_{\mathrm{x}}$ emissions will result in an increase in the 448 concentrations of oxidants such as $\mathrm{O}_{3}$ and $\mathrm{HO}_{\mathrm{x}}$. The elevated concentrations of those oxidants and radicals accelerate the generation of secondary organic and inorganic aerosols such as 
sulfate and nitrate, which compensates the effect of the decreased $\mathrm{NO}_{\mathrm{x}}$ concentrations on the nitrate formation. The declined $\mathrm{PM}_{2.5}$ concentrations occur over southern China such as eastern area of Sichuan, Chongqing City, Guizhou, Guangxi, and Hunan, by 5-30 $\mu \mathrm{g} \mathrm{m}^{-3}$ (by 5-13\%) which is also consistent with the results of Zhao et al. (2013). $\mathrm{PM}_{2.5}$ concentrations are more sensitve to reductions in $\mathrm{NH}_{3}$ emissions in southern China, i.e., along and in regions located in the south of the Yangtze River. A 30\% reduction of $\mathrm{NH}_{3}$ emissions results in a decrease of roughly 5-15 $\mu \mathrm{g} \mathrm{m}{ }^{-3}$ in $\mathrm{PM}_{2.5}$ concentrations, accounting for $2-8 \%$ of baseline $\mathrm{PM}_{2.5}$ concentrations. There are not significant changes in $\mathrm{PM}_{2.5}$ concentrations over $\mathrm{NCP}$, due to the $\mathrm{NH}_{3}$-rich condition over this area. Reduction in VOCs emissions, as shown in Figure 4e, reduces $\mathrm{PM}_{2.5}$ concentrations over eastern China, especially over NCP, Henan, Jiangsu, and Anhui, by $5-50 \mu \mathrm{g} \mathrm{m}^{-3}$ (by 4-18\%) which is consistent with the VOC-limited regime where the reduced VOCs concentrations result in a decrease in oxidants concentrations that leads to the decrease of sulfate and nitrate concentrations. The secondary organic aerosols are decreased, due to decreases in both oxidants concentrations and primary VOCs emissions.

The combined emission controls, e.g., reducing $\mathrm{SO}_{2}, \mathrm{NO}_{\mathrm{x}}$, and $\mathrm{NH}_{3}$ emissions simutaneously by $30 \%$, reduce the $\mathrm{PM}_{2.5}$ concentrations over southern China by $5-40 \mu \mathrm{g} \mathrm{m}^{-3}$ (2-17\%, see Figure 4f), but slightly increase those in the intersection area of Hebei, Henan, and Shandong provinces, due to the characteristics of $\mathrm{NH}_{3}$-rich and VOC-limited conditions in those areas. When emissions of the four primary pollutants, $\mathrm{SO}_{2}, \mathrm{NO}_{\mathrm{x}}, \mathrm{NH}_{3}$, and VOC are controlled simultaneously, as shown in Figure $4 \mathrm{~g}$, the $\mathrm{PM}_{2.5}$ concentrations decrease over most areas of eastern and southern China, by $5-41 \mu \mathrm{g} \mathrm{m}^{-3}$, which corresponds to $2-17 \%$ of the $\mathrm{PM}_{2.5}$ concentrations predicted by BASE_EMIS. These results imply that $\mathrm{NO}_{\mathrm{x}}$ emissions controls, which are considered to be one of the major tasks in the China national pollution 
control plan (Zhao et al., 2013), should be accompanied with the controls of other pollutants,

475

476

477

478

479

480

481

482

483

484

485

486

487

488

489

490

491

492

493

494

495

496

497 especially VOCs, which is important to reduction of the severe $\mathrm{PM}_{2.5}$ pollution during the winter time over NCP, the top polluted area in China.

\section{Conclusions}

In this study, the online-coupled meteorology-air quality model, WRF/Chem, is applied to simulate the extremely severe haze pollution in January 2013 over East Asia and the north China at 36- and 12-km grid resolutions, respectively. A total of 11 simulations are conducted to examine the sensitivities of the model predictions to the physical schemes, i.e., shortwave and longwave radiation schemes, land surface and surface layer models, planetary boundary layer scheme, cumulus parameterization, and microphysics scheme. The results show that all simulations perform similarly for T2, Q2, WS10, and WD10, but give substantially different precipitation predictions. Using a smaller nudging coefficient of $1 \times 10^{-5}$ for water vapor mixing ratio, instead of the original $3 \times 10^{-4}$, significantly reduces the negative bias of precipitation predictions. The concentrations of four major pollutants, $\mathrm{PM}_{2.5}, \mathrm{PM}_{10}, \mathrm{SO}_{2}, \mathrm{NO}_{2}$, and $\mathrm{CO}$ are overpredicted due mainly to the lack of wet scavenging for the SAPRC99MOSAIC/VBS option in WRF/Chem versions 3.5 and 3.5.1. The optimal configuration with the best overall performance identified in this work is RAD_MP_KF_Q, that is, the simulation with the Gorddard shortwave and RRTM longwave radiation schemes, the Purdue Lin microphysics scheme, the Kain-Fritsch cumulus scheme, and a nudging coefficient of $1 \times 10^{-5}$ for water vapor mixing ratio. The nested simulation at the $12-\mathrm{km}$ resolution improves the performance for $\mathrm{PM}_{2.5}$ and $\mathrm{PM}_{10}$ but deteriorates that for $\mathrm{SO}_{2}, \mathrm{NO}_{2}$, and $\mathrm{CO}$, partially because of the uncertainties in the spatial allocation of the emissions into a finer grid resolution. 
499 are more sensitive to the emissions of $\mathrm{NO}_{\mathrm{x}}, \mathrm{SO}_{2}$, and VOCs than those of $\mathrm{NH}_{3}$. While a $30 \%$

500 reduction in the emissions of $\mathrm{SO}_{2}$ and VOCs leads to a decrease of 2-15 $\mu \mathrm{g} \mathrm{m}^{-3}$ and $5-50 \mu \mathrm{g}$

$501 \mathrm{~m}^{-3}$, respectively, in $\mathrm{PM}_{2.5}$ concentrations, $\mathrm{NO}_{\mathrm{x}}$ emission reduction adversely increases the

$502 \mathrm{PM}_{2.5}$ concentrations by $2-25 \mu \mathrm{g} \mathrm{m}^{-3}$, due to the $\mathrm{NH}_{3}$-rich and VOC-limited atmospheric

503 conditions over northern China. In southern China, $\mathrm{PM}_{2.5}$ concentrations are more sensitive to 504 emissions of $\mathrm{NO}_{x}$ and $\mathrm{NH}_{3}$. A 30\% reduction of $\mathrm{NO}_{\mathrm{x}}$ emissions leads to a decrease of 5-30 $\mu \mathrm{g}$ $505 \mathrm{~m}^{-3}$ in $\mathrm{PM}_{2.5}$ concentrations and the reduction of $\mathrm{NH}_{3}$ emissions results in a decrease of 506 roughly $5-15 \mu \mathrm{g} \mathrm{m}^{-3}$. Reductions of VOCs emissions reduce $\mathrm{PM}_{2.5}$ over eastern China by 507 about 5-50 $\mu \mathrm{g} \mathrm{m}^{-3}$. While the combined emission controls of $\mathrm{SO}_{2}, \mathrm{NO}_{\mathrm{x}}$, and $\mathrm{NH}_{3}$ by $30 \%$ 508 leads to a large reduction in $\mathrm{PM}_{2.5}$ concentrations over southern China, it increases $\mathrm{PM}_{2.5}$ 509 concentrations in northern China. When the emissions of $\mathrm{SO}_{2}, \mathrm{NO}_{\mathrm{x}}, \mathrm{NH}_{3}$, and VOCs are 510 controlled simultaneously, the $\mathrm{PM}_{2.5}$ concentrations decrease over most areas of eastern and 511 southern China by roughtly $5-41 \mu \mathrm{g} \mathrm{m}^{-3}$ (by $2-17 \%$ ). The results in this work indicate that 512 more aggressive, combined emission control strategies are needed to mitigate the severe 513 pollution over nothern China to reach the objective of $25 \% \mathrm{PM}_{2.5}$ concentration reduction in 5142017 proposed in the Action Plan for Air Pollution Prevention and Control by the State 515 Concil in 2013.

\section{Acknowledgements}

518 This study was co-sponsored by the National Natural Science Foundation of China (No.

519 41475131, 41105105), the Natural Science Foundation of Hebei Province (No. 520 D2011402019), the State Environmental Protection Key Laboratory of Sources and Control of Air Pollution Complex (No. SCAPC201307), the Excellent Young Scientist Foundation of 
522 Hebei Education Department (No. YQ2013031), the Program for the Outstanding Young

523 Scholars of Hebei Province, the China Scholarship Council, and the Handan Environmental 524 Protection Bureau at HEBEU, China, and the U.S. DOE climate modeling programs 525 (DESC0006695) at NCSU, U.S.A. Thanks are due to Robert Gilliam, the U.S. EPA, for 526 providing valuable suggestions to apply a lower nudging coefficient to improve precipitation 527 predictions.

This study used computer resources of the National Energy Research Scientific

Computing Center (HOPPER), which is supported by the Office of Science of the U.S.

Department of Energy under Contract No. DE-AC02-05CH11231, and the Extreme Science and Engineering Discovery Environment (XSEDE) (STAMPEDE), which is supported by

National Science Foundation grant number OCI-1053575.

\section{References}

An, J. L., Li, Y., Chen, Y., Li, J., Qu, Y., and Tang, Y. J.: Enhancements of major aerosol components due to additional HONO sources in the North China Plain and implications for visibility and haze, Advances in Atmospheric Sciences, 30(1), 57-66, 2013.

Boylan, J. W., Russell, A. G.: PM and light extinction model performance metrics, goals, and criteria for three-dimensional air quality models, Atmos. Environ., 40, 4946-4959, 2006.

540 Carter, W. P. L.: A Detailed Mechanism for the Gas-Phase Atmospheric Reactions of Organic Compounds, Atmos. Environ., 24, 481-518, 1990.

542 Carter, W. P. L.: Implementation of the SAPRC99 chemical mechanism into the Models-3

543 Framework, Report to the U.S. EPA, Statewide Air Pollution Research Center, University 544 of California, Riverside, CA, USA, 2000.

545 Chen, F., and J. Dudhia: Coupling an advanced land surface-hydrology model with the Penn 
State NCAR MM5 modeling system. Part I: Model implementation and sensitivity, Mon.

$547 \quad$ Weather Rev., 129, 569-585, 2001.

548 Chen, S. H., and W. Y. Sun: A one dimensional time dependent cloud model, J. Meteorol. $549 \quad$ Soc. Jpn., 80, 99-118, doi:10.2151/jmsj.80.99, 2002.

550 Chen, D. S., Cheng, S. Y., Liu, L., Chen, T., and Guo, X. R.: An integrated MM5-CMAQ 551 modeling approach for assessing trans-boundary $\mathrm{PM}_{10}$ contribution to the host city of

Chen, D. S., Cheng, S.Y., Liu, L., Lei, T., Guo, X. R., and Zhao, X. Y.: Assessment of the Integrated ARPS-CMAQ Modeling System through Simulating $\mathrm{PM}_{10}$ Concentration in Beijing, China, Environ. Eng. Sci., 25(2), 191-206, 2008.

Chen, S. Y., Huang, J. P., Zhao, C., Qian, Y., Leung, L. R., and Yang, B.: Modeling the transport and radiative forcing of Taklimakan dust over the Tibetan Plateau: A case study in the summer of 2006, J. Geophys. Res., 118, 797-812, doi:10.1002/jgrd.50122, 2013.

Chou, M. D., M. J. Suarez, C. H. Ho, M. M. H. Yan, and K. T. Lee: Parameterizations for cloud overlapping and shortwave single scattering properties for use in general circulation and cloud ensemble models, J. Clim., 11, 202-214, 1998.

Ek, M. B., K. B. Mitchell, Y. Lin, B. Rogers, P. Grunmann, V. Koren, G. Gayno, and J. D. Tarpley: Implementation of NOAH land surface model advances in the National Centers for Environmental Prediction operational mesoscale Eta model, J. Geophys. Res., 108(D22), 8851, doi:10.1029/2002JD003296, 2003.

Fast, J. D., W. I. Gustafson Jr., R. C. Easter, R. A. Zaveri, J. C. Barnard, E. G. Chapman, G. A. Grell, and S. E. Peckham: Evolution of ozone, particulates, and aerosol direct radiative forcing on the vicinity of Houston using a fully coupled meteorology-chemistry-aerosol model, J. Geophys. Res., 111, D21305, doi:10.1029/2005JD006721, 2006. 
570 Fu, J. S, Streets, D. G., Jang, C. J., Hao, J. M., He, K. B., Wang, L. T., and Zhang, Q:

571

572

573

574

575

576

577

578

579

580

581

582

583

584

585

586

587

588

589

590

591

592

593 Modeling Regional/Urban Ozone and Particulate Matter in Beijing, China, J. Air \& Waste Manage. Assoc., 59, 37-44, 2009.

Gao, Y. and Zhang, M. G.: Sensitivity analysis of surface ozone to emission controls in Beijing and its neighboring area during the 2008 Olympic Games, J. of Environ. Sci.China, 24(1), 50-61, 2012.

Garrett, T. J., Avey, L., Palmer, P. I., Stohl, A., Neuman, J. A., Brock, C. A., Ryerson, T. B., Holloway, J. S.: Quantifying wet scavenging processes in aircraft observations of nitric acid and cloud condensation nuclei, J. Geophy. Res., 111, D23S51, doi:10.1029/2006JD007416, 2006.

Ginoux, P., M. Chin, I. Tegen, J. Prospero, B. Holben, O. Dubovik, and S.J. Lin: Sources and global distributions of dust aerosols simulated with the GOCART model, J. Geophys. Res., 106, 20,255-20,273, 2001.

Gong, S. L.: A parameterization of seasalt aerosol source function for sub and supermicron particles, Global Biogeochem. Cy., 17(4), 1097, doi:10.1029/2003GB002079, 2003.

Grell, G. A., and D. Devenyi: A generalized approach to parameterizing convection combining ensemble and data assimilation techniques, Geophys. Res. Lett., 29(14), 1693, doi:10.1029/2002GL015311, 2002.

Grell, G. A., S. E. Peckham, R. Schmitz, S. A. McKeen, G. Frost, W. C. Skamarock, and B. Eder: Fully coupled "online" chemistry within the WRF model, Atmos. Environ., 39, 6957-6975, doi:10.1016/j.atmosenv.2005.04.027, 2005.

Guenther, A., T. Karl, P. Harley, C. Wiedinmyer, P. I. Palmer, and C. Geron: Estimates of global terrestrial isoprene emissions using MEGAN (Model of Emissions of Gases and Aerosols from Nature), Atmos. Chem. Phys., 6, 3181-3210, 2006. 
Han, S. Q., Feng, Y. C., Bian, H., Tie, X., Xie, Y. Y., Li, X. J., and Sun, M. L.: Numerical simulation of diurnal variation of major pollutants with WRF-Chem model in Tianjin, China Environmental Science, 28(9), 828-832, 2008. (In Chinese)

He, K. B.: Multi-resolution Emission Inventory for China (MEIC): model framework and 1990-2010 anthropogenic emissions, Presented on the International Global Atmospheric Chemistry Conference, September 17-21, Beijing, China, 2012.

Hong, S., Y. Noh, and J. Dudhia: A new vertical diffusion package with an explicit treatment of entrainment processes, Mon. Weather Rev., 134, 2318-2341, doi:10.1175/MWR3199.1, 2006.

Huang, R. J., Zhang, Y. L., Bozzetti, C., Ho, K. F., Cao, J. J., Han, Y. M., Daellenbach, K. R., Slowik, J. G., Platt, S. M., Canonaco, F., Zotter, P., Wolf, F., Pieber, S., Bruns, E. A., Crippa, M., Ciarelli, G., Piazzalunga, A., Schwikowski, M., Abbaszade, G., SchnelleKreis, J., Zimmermann, R., An, Z., Szidat, S., Baltensperger, Imad El Haddad, U., Prevot, A. S. H.: High secondary aerosol contribution to particulate pollution during haze events in China, Nature, doi:10.1038/nature13774, 2014.

Iacono, M. J., Delamere, J. S., Mlawer, E. J., Shephard, M. W., Clough, S. A., and Collins, W. D.: Radiative forcing by longlived greenhouse gases: Calculations with the AER radiative

Ikeda R. and H. Kusaka: Proposing the Simplification of the Multilayer Urban Canopy Model:

613 Intercomparison Study of Four Models, J. Appl. Meteor. Climatol., 49, 902-919. doi: 614 http://dx.doi.org/10.1175/2009JAMC2336.1, 2010.

615 Janjić, Z. I.: Nonsingular Implementation of the Mellor-Yamada Level 2.5 Scheme in the 616 NCEP Meso Model, NCEP Off. Note 437, 61 pp., Natl. Cent. for Environ. Predict., Camp 617 Springs, Md., 2001. 
Ji, D. S., Li, L., Wang, Y. S., Zhang, J. K., Cheng, M. T., Sun, Y., Liu, Z. R., Wang, L. L.,

619 Tang, G. Q., Hu, B., Chao, N., Wen, T. X., Miao, H. Y.: The heaviest particulate air620 pollution episodes occurred in northern China in January, 2013: Insights gained from 621 observation, Atmos. Environ., 92, 546-556, 2014.

622 Jiang, J. K., Zhou, W., Cheng, Z., Wang, S. X., He, K. B., Hao, J. M.: Particulate Matter 623 Distributions in China during a Winter Period with Frequent Pollution Episodes (January 624 2013), Aerosol and Air Quality Research, 2014. (In press)

625

Kain, J. S.: The Kain Fritsch convective parameterization: An update, J. Appl. Meteor., 43, 170-181, 2004.

Knote, C., Brunner, D.: An advanced scheme for wet scavenging and liquid-phase chemistry in a regional online-coupled chemistry transport model, Atmos. Chem. Phys., 13, 1177$1192,2013$.

630

Kusaka, H. and Kimura, F: Thermal effects of urban canyon structure on the nocturnal heat island: Numerical experiment using a mesoscale model coupled with and urban canopy model, J. Appl. Meteor., 43, 1899-1910, 2004.

Li, N., Fu, T. M., Cao, J. J., Lee, S. C., Huang, X. F., He, L. Y., Ho, K. F., Fu, J. S., and Lam, Y. F.: Sources of secondary organic aerosols in the Pearl River Delta region in fall: Contributions from the aqueous reactive uptake of dicarbonyls, Atmos. Environ., 76(S1), 200-207, 2013.

Li, M., Zhang, Q., Streets, D. G., et al.: Mapping Asian anthropogenic emissions of nonmethane volatile organic compounds to multiple chemical mechanisms. Atmos. Chem. Phys., 14, 5617-5638, 2014.

640 Lim, K. S. and Hong, S. Y.: Development of an Effective Double Moment Cloud 641 Microphysics Scheme with Prognostic Cloud Condensation Nuclei (CCN) for Weather 

and Climate Models, Mon. Wea. Rev., 138, 1587-1612, 2010.

643 Lin, Y. L., R. D. Farley, and H. D. Orville: Bulk parameterization of the snow field in a cloud 644 model, J. Clim. Appl. Meteorol., 22, 1065-1092, 1983.

645 Lin, M., Holloway, T., Oki, T., Streets, D. G., Richter, A.: Multi-scale model analysis of 646 boundary layer ozone over East Asia, Atmos. Chem. Phys., 9, 3277-3301, 2009.

647 Liu, X. H., Zhang, Y., Xing, J., Zhang, Q., Wang, K., Streets, D. G., Jang, C. J., Wang, W. X., 648 Hao, J. M.: Understanding of regional air pollution over China using CMAQ, part II. 649 Process analysis and sensitivity of ozone and particulate matter to precursor emissions, $650 \quad$ Atmos. Environ., 44, 3719-3727, 2010.

651 Lu, X. Y., Tang, J., Zhang, J., Yue, J., Song, G. K., and Hu, J. G.: Annual report on analysis 652

Madronich, S. and S. Flocke: The role of solar radiation in atmospheric chemistry, in 654 Handbook of Environmental Chemistry (P. Boule, ed.), Springer_Verlag, Heidelberg, pp. 126,1998

Misenis, C. and Zhang, Y.: An examination of sensitivity of WRF/Chem predictions to physical parameterizations, horizontal grid spacing, and nesting options, Atmos. Res., 97,

Mlawer, E. J., S. J. Taubman, P. D. Brown, M. J. Iacono, and S. A. Clough: Radiative 660 transfer for inhomogeneous atmospheres: RRTM, a validated correlated k model for the longwave, J. Geophys. Res., 102, (D14), 16,663-16,682, doi:10.1029/97JD00237, 1997.

Monin, A. S., and A. M. Obukhov: Basic laws of turbulent mixing in the surface layer of the

664 atmosphere [in Russian], Tr. Geophiz. Inst. Akad. Nauk. SSSR, 24(151), 163-187, 1954.

Morrison, H., G. Thompson, and V. Tatarskii: Impact of Cloud Microphysics on the 665 Development of Trailing Stratiform Precipitation in a Simulated Squall Line: Comparison 
of One and Two Moment Schemes, Mon. Wea. Rev., 137, 991-1007. doi: http://dx.doi.org/10.1175/2008MWR2556.1, 2009.

NBS: China Statistical Yearbook 2013. China Statistical Press, Beijing, China, 2013.

NCAR: Advanced Research WRF (ARW) Version 3.5 modeling system User's Guide, NCAR, USA, 2013.

Peckham, S. E., Grell, G. A., McKeen, S. A., Ahmadov, R., Brarth, M., Pfister, G., Wiedinmyer, C., Fast, J. D., Gustafson, W. I., Ghan, S. J., Zaveri, R., Easter, R. C., WRF/Chem Version 3.5 User's Guide, NOAA, USA, 2013.

Pleim, J. E. and Xiu, A.: Development and testing of a surface flux and planetary boundary layer model for application in mesoscale models, J. Appl. Meteorol., 34, 16-32, 1995.

Pleim, J. E.: A simple, efficient solution of flux profile relationships in the atmospheric surface layer, J. Appl. Meteor. and Clim., 45, 341-347, 2006.

Pleim, J. E.: A Combined Local and Nonlocal Closure Model for the Atmospheric Boundary Layer. Part I: Model Description and Testing. J. Appl. Meteor. Climatol., 46, 1383-1395, 2007.

682

Saide, P. E., Spak, S. N., Carmichael, G. R., Mena-Carrasco, M. A., Yang, Q., Howell, S., 683 Leon, D. C., Snider, J. R., Bandy, A. R., Collett, J. L., Benedict, K. B., de Szoeke, S. P.,

Shrivastava, M., Fast, J., Easter, R., Gustafson Jr., W. I., Zaveri, R. A., Jimenez, J. L., Saide, 688 P., and Hodzic, A.: Modeling organic aerosols in a megacity: comparison of simple and 
691 Situ, S., Guenther, A., Wang, X., Jiang, X., Turnipseed, A., Wu., Z., Bai, J., and Wang, X.: 692 Impacts of seasonal and regional variability in biogenic VOC emissions on surface ozone in the Pearl River delta region, China, Atmos. Chem. Phys., 13, 11803-11817, 2013.

Streets, D. G., Fu, J. S., Jang, C. J., Hao, J. M., He, K. B., Tang, X. Y., Zhang, Y. H., Wang, Z. F., Li, Z. P., Zhang, Q., Wang, L. T., Wang, B. Y., and Yu, C.: Air quality during the 2008 Beijing Olympic Games, Atmos. Environ., 41, 480-492, 2007.

697

Tie, X. X., Geng, F. H., Peng, L., Gao, W., and Zhao, C. S.: Measurement and modeling of 698 O3 variability in Shanghai, China: Application of the WRF-Chem model, Atmos. Environ., 43(28), 4289-4302, 2009.

700

Tie, X. X., Geng, F., Guenther, A., Cao, J., Greenberg, J., Zhang, R., Apel, E., Li, G., 701 Weinheimer, W., Chen, J., and Cai, C: Megacity impacts on regional ozone formation: observations and WRF-Chem modeling for the MIRAGE-Shanghai field campaign, Atmos. Chem. Phys., 13, 5655-5669, 2013.

Tonnesen, G. S. and Dennis, R. L.: Analysis of radical propagation efficiency to assess ozone 705 sensitivity to hydrocarbons and NOx 1. Local indicators of instantaneous odd oxygen production sensitivity, J. of Geophys. Res., 105 (D7), 9213-9225, 2000a.

707

Tonnesen, G. S. and Dennis, R. L.: Analysis of radical propagation efficiency to assess ozone 708 sensitivity to hydrocarbons and NOx 2. Long-lived species as indicators of ozone concentration sensitivity, J. of Geophys. Res., 105 (D7), 9227-9241, 2000 b.

710 Tuccella., P., Curci, G., Visconti, G., Bessagnet, B., Menut, L., and Park, R. J. : Modeling of 711 gas and aerosol with WRF/Chem over Europe: Evaluation and sensitivity study, J. Geophys. Res., 117, D03303, doi:10.1029/2011JD016302, 2012.

713 U.S. EPA: Guidance on the Use of Models and Other Analyses for Demonstrating 
Attainment of Air Quality Goals for Ozone, $\mathrm{PM}_{2.5}$, and Regional Haze. Office of Air and Radiation/Office of Air Quality Planning and Standards, Research Triangle Park, NC, USA, 2007.

Wang, L. T., Hao, J. M., He, K. B., Wang, S. X., Li, J., Zhang, Q., Streets, D. G., Fu, J. S., Jang, C. J., Takekawa, H, and Chatani, S: A modeling study of coarse particulate matter pollution in Beijing: regional source contributions and control implications for the 2008 Summer Olympics, J. Air \& Waste Manage. Assoc., 58, 1057-1069. doi:10.3155/10473289.58.8.1057, 2008.

Wang, K., Zhang, Y., Jang, C. J., Phillips, S., and Wang, B. Y.: Modeling study of intercontinental air pollution transport over the trans-pacific region in 2001 using the community multiscale air quality (CMAQ) modeling system, J. of Geophys. Res., 114 (D4), D04307, doi:10.1029/2008JD010807, 2009.

Wang, S. X., Xing, J., Jang, C. J., Zhu, Y., Fu, J. S., and Hao, J. M.: Impact assessment of ammonia emissions on inorganic aerosols in east China using response surface modeling technique, Environ. Sci. \& Tech., 45, 9293-9300, 2011.

Wang, J. D., Wang, S. X., Jiang, J. K., Ding, A. J., Zheng, M., Zhao, B., Wong, D. C., Zhou, W., Zheng, G. J., Wang, L., Pleim, J. E., Hao, J. M.: Impact of aerosol-meteorology interactions on fine particle pollution during China's severe haze episode in January 2013, Environ. Res. Lett., 9, 094002, doi:10.1088/1748-9326/9/9/094002, 2014.

Wang, L. T., Wei, Z., Yang, J., Zhang, Y., Zhang, F. F., Su, J., Meng, C. C., and Zhang, Q: The 2013 severe haze over southern Hebei, China: model evaluation, source apportionment, and policy implications, Atmos. Chem. Phys., 14, 3151-3173, doi:10.5194/acp-14-3151-2014, 2014.

Wang, Y. S., Yao, L., Wang, L. L., Liu, Z. R., Ji, D. S., Tang, G. Q., Zhang, J. K., Sun, Y., 

Hu, B., Xin, J. Y.: Mechanism for the formation of the January 2013 heavy haze pollution episode over central and eastern China, Science China Earth Sciences, 57(1), 14-25, 2014.

Wei, Z., Yang, J., Wang, L. T., Wei, W., Zhang, F. F., and Su, J.: Characteristics of the severe haze episode in Handan city in January, 2013, Acta Scientiae Circumstantiae, 34(5), 1118-1124, 2014, (in Chinese).

Wu, L. T., Su, H., and Jiang, J. H.: Regional simulation of aerosol impacts on precipitation during the East Asian summer monsoon, J. Geophys. Res., 118, 6454-6467, doi:10.1002/jgrd.50527, 2013.

Xing, J., Zhang, Y., Wang, S. X., Liu, X. H., Cheng, S. H., Zhang, Q., Chen, Y. S., Streets, D., G., Jang, C. J., Hao, J. M., and Wang, W. X.: Modeling study on the air quality impacts from emission reductions and a typical meteorological conditions during the 2008 Beijing Olympics, Atmos. Environ., 45, 1786-1798, 2011.

Xiu, A. and Pleim, J. E.: Development of a land surface model. part I: application in a mesoscale meteorological model, J. Appl. Meteorol., 40, 192-209, 2001.

Yan, R. S.: Simulation and Analysis of Wintertime Typical Particulate Matter Pollution Episode in Beijing, Master thesis, Nanjing University of Information Science and

Zaveri, R. A., Easter, R. C., Fast, J. D., and Peters, L. K.: Model for simulating aerosol interactions and chemistry (MOSAIC), J. Geophys. Res., 113, D13204, doi:10.1029/2007JD008792, 2008.

Zhang, Y., Liu, P., Pun, B., and Seigneur, C.: A comprehensive performance evaluation of MM5-CMAQ for the Summer 1999 Southern Oxidants Study episode-Part I: Evaluation protocols, databases, and meteorological predictions, Atmos. Environ., 40, 4825-4838, 2006. 
Zhang, Y.: Online Coupled Meteorology and Chemistry models: History, Current Status, and Outlook, Atmos. Chem. Phys., 8, 2895-2932, 2008.

Zhang Q., Streets, D. G., Carmichael, G. R., K. B. He, H. Huo, A. Kannari, Z. Klimont, I. S. Park, S. Reddy, J. S. Fu, D. Chen, L. Duan, Y. Lei, L. T. Wang, and Z. L. Yao.: Asian emissions in 2006 for the NASA INTEX-B mission. Atmos. Chem. Phys., 9, 5131-5153, 2009.

Zhang, Y., Wen, X. Y., Wang, K., Vijayaraghavan, K., Jacobson, M. Z.: Probing into regional $\mathrm{O}_{3}$ and particulate matter pollution in the United States: 2. An examination of formation mechanisms through a process analysis technique and sensitivity study, J. of Geophys. Res., 114, D22305, doi:10.1029/2009JD011900, 2009.

Zhang, Y., Wen, X. Y., Jang, C. J.: Simulating chemistry-aerosol-cloud-radiation-climate feedbacks over the continental U.S. using the online-coupled Weather Research Forecasting Model with chemistry (WRF/Chem), Atmos. Environ., 44, 3568-3582, 2010a.

Zhang, Y., Liu, X. H., Olsen, K. M., et al.: Responses of future air quality to emission controls over North Carolina, Part II: Analyses of future-year predictions and their policy implications, Atmos. Environ., 44, 2767-2779, $2010 b$.

Zhang, Y., Bocquet, M., Mallet, V., Seigneur, C., and Baklanov, A.: Real-time air quality forecasting, part I: History, techniques, and current status, Atmos. Environ., 60, 632-655, $2012 \mathrm{a}$.

Zhang, Y., Chen, Y. S., Sarwar, G., Schere, K.: Impact of gas-phase mechanisms on Weather Research Forecasting Model with Chemistry (WRF/Chem) predictions: Mechanism implementation and comparative evaluation, J. Geophys. Res., 117, D01301, doi:10.1029/2011JD015775, 2012b.

Zhang, Y., Karamchandani, P., Glotfelty, T., Streets, D. G., Grell, G., Nenes, A., Yu, F. Q., 
Bennartz, R.: Development and initial application of the global-through-urban weather research and forecasting model with chemistry (GU-WRF/Chem), J. Geophys. Res., 117, D20206, doi:10.1029/2012JD017966, 2012c.

Zhang, Y., Sartelet, K., Zhu, S., Wang, W., Wu, S. Y., Zhang, X., Wang, K., Trans, P., 790 Seigneur, C., Wang, Z. F.: Application of WRF/Chem-MADRID and WRF/Polyphemus 791 in Europe - Part 2: Evaluation of chemical concentrations and sensitivity simulations, 792 Atmos. Chem. Phys., 13, 6845-6875, 2013.

Zhao, B., Wang, S. X., Wang, J. D., Fu, J. S., Liu, T. H., Xu, J. Y., Fu, X., Hao, J. M.: Impact of national NOx and SO2 control policies on particulate matter pollution in China, Atmos. Environ., 77, 453-463, 2013.

Zheng, G. J., Duan, F. K., Ma, Y. L., Cheng, Y., Zheng, B., Zhang, Q., Huang, T., Kimoto, T., 797 Chang, D., Su, H., Pöschl, U., Cheng, Y. F., He, K. B.: Exploring the severe winter haze in Beijing, Atmos. Chem. Phys. Discuss., 14, 17907-17942, 2014.

Zhou, Y., Fu, J. S., Zhuang, G. S., and Levy, J. I.: Risk-Based Prioritization among Air 800 Pollution Control Strategies in the Yangtze River Delta, China, Environ. Health Perspec., $801 \quad 118(9), 1204-1210,2010$.

Zhou, Y., Cheng, S. Y., Liu, L., and Chen, D. S.: A Coupled MM5-CMAQ Modeling System 803 for Assessing Effects of Restriction Measures on $\mathrm{PM}_{10}$ Pollution in Olympic City of Beijing, China, J. of Environ. Informatics, 19(2), 120-127, 2012. 
Table 1. Model configurations used in WRF/Chem simulations.

807 a. Physical and chemical options used in the baseline and sensitivity simulations.

\begin{tabular}{|c|c|c|}
\hline Physical and chemical processes & Baseline simulations & Sensitivity simulations \\
\hline Simulation period & January 1-31, 2013 & The same as baseline \\
\hline Domain & East Asia (36-km), northern China (12-km) & The same as baseline \\
\hline Horizontal resolution & $36-\mathrm{km}$ and12-km & The same as baseline \\
\hline Vertical resolution & 23 layers from $1000-100 \mathrm{mb}$ & The same as baseline \\
\hline Anthropogenic emissions & MEIC [http://www.meicmodel.org/] & $\begin{array}{l}\text { The same as baseline but with } 30 \% \\
\text { reduction in } \mathrm{SO}_{2}, \mathrm{NO}_{\mathrm{x}}, \mathrm{NH}_{3}, \text { and } \\
\text { VOCsemissions individually } \\
\text { collectively. }\end{array}$ \\
\hline Biogenic emissions & MEGAN 2 [Guenther et al., 2006] & The same as baseline \\
\hline Dust emissions & GOCART dust emissions [Ginoux et al., 2001] & The same as baseline \\
\hline Sea-salt emissions & Gong [2003] & The same as baseline \\
\hline Meteorological ICs and BCs & $\begin{array}{l}\text { The National Centers for Environmental Prediction Final } \\
\text { Analysis (NCEP-FNL) reanalysis data }\end{array}$ & The same as baseline \\
\hline Chemical IC and BC & $\begin{array}{l}\text { Default for } 36-\mathrm{km} \text {; nested down from the parent domain } \\
\text { for } 12-\mathrm{km}\end{array}$ & The same as baseline \\
\hline Gas-phase chemistry & SAPRC-99 [Carter, 2000] & The same as baseline \\
\hline Photolysis & Madronich F-TUV [Madronch and Flocke,1998] & The same as baseline \\
\hline Aerosol module & $\begin{array}{l}\text { 4-bin MOSAIC aerosol with volatility basis set (VBS) } \\
\text { [Zaveri et al., 2008; Shrivastava et al., 2011] }\end{array}$ & The same as baseline \\
\hline Urban surface & $\begin{array}{l}\text { Urban canopy model [Kusaka and Kimura, 2004; Ikeda } \\
\text { and Kusaka, 2010] }\end{array}$ & The same as baseline \\
\hline Shortwave radiation & RRTMG [Iacono et al., 2008] & Goddard [Chou et al., 1998] \\
\hline Longwave radiation & RRTMG [Iacono et al., 2008] & RRTM [Mlawer et al., 1997] \\
\hline Land surface & $\begin{array}{l}\text { NOAH Land Surface Model [Chen and Dudhia, 2001; } \\
\text { Ek et al., 2003] }\end{array}$ & $\begin{array}{l}\text { Pleim-Xiu [Pleim and Xiu, 1995; Xiu and } \\
\text { Pleim, 2001] }\end{array}$ \\
\hline Surface layer & $\begin{array}{l}\text { Monin-Obukhov [Monin and Obukhov, 1954; Janjic, } \\
\text { 2001] }\end{array}$ & Pleim-Xiu [Pleim, 2006] \\
\hline PBL & Yonsei University Scheme (YSU) [Hong et al., 2006] & ACM2 scheme [Pleim, 2007] \\
\hline Cumulus & Grell 3D ensemble [Grell and Devenyi, 2002] & $\begin{array}{l}\text { Grell-Devenyi emsemble [Grell and } \\
\text { Devenyi, 2002]; } \\
\text { Kain-Fritsch [Kain, 2004] }\end{array}$ \\
\hline Microphysics & Morrison double-moment [Morrison et al., 2009] & $\begin{array}{l}\text { Purdue Lin [Lin et al., 1983; Chen and Sun, } \\
\text { 2002]; WDM6 [Lim and Hong, 2010] }\end{array}$ \\
\hline
\end{tabular}

b. Model configurations and simulation indices in the baseline and sensitivity simulations.

\begin{tabular}{|c|c|c|}
\hline Simulation index & Configuration & Notes \\
\hline BASE & Baseline, see Table 1(a) & \\
\hline RAD & Gorddard shortwave and RRTM longwave schemes & Others are same as BASE \\
\hline MP & Purdue Lin microphysics scheme & Others are same as BASE \\
\hline CU_GD & Grell-Devenyi emsemble cumulus scheme & Others are same as BASE \\
\hline CU_KF & Kain-Fritsch cumulus scheme & Others are same as BASE \\
\hline RAD_MP_KF & RAD; MP; Kain-Fritsch cumulus scheme & Others are same as BASE \\
\hline $\begin{array}{l}\text { RAD_MP_KF_Q } \\
\text { (BASE_EMIS for emission sensitivity } \\
\text { simulations) }\end{array}$ & $\begin{array}{l}\text { RAD_MP_KF; nudging coefficient for Q changed from } 3 \times 10^{-4} \text { to } \\
1 \times 10^{-5}\end{array}$ & Others are same as BASE \\
\hline RAD_MP_KF_TRI & RAD_MP_KF; kfeta_trigger=2 for KF cumulus physics scheme & Others are same as BASE \\
\hline RAD_WDM6_KF & RAD; WDM6 microphysics scheme; Kain-Fritsch cumulus scheme & Others are same as BASE \\
\hline PX_RAD_MP_KF_351 & $\begin{array}{l}\text { Pleim-Xiu land surface and surface layer scheme; ACM2 PBL } \\
\text { scheme; RAD_MP_KF; using WRF/Chem 3.5.1 }\end{array}$ & Others are same as BASE \\
\hline PX_RAD_MP_KF_351 & Pleim-Xiu land surface and surface layer scheme; ACM2 PBL & Others are same as BASE \\
\hline
\end{tabular}


$\mathrm{SO}_{2} 30$

$\mathrm{NO}_{\mathrm{x}-} 30$

$\mathrm{NH}_{3} \_30$

VOCs_30

$\mathrm{SO}_{2} \mathrm{NO}_{\mathbf{X}} \mathrm{NH}_{3} 30$

$\mathrm{SO}_{2} \_\mathrm{NO}_{\mathrm{X} \_} \mathrm{NH}_{3} \_\mathrm{VOCs} \_30$ scheme; RAD_MP_KF; Nudging coefficient for Q changed from $3 \times 10^{-4}$ to $1 \times 10^{-5}$; using WRF/Chem 3.5.1

$\mathrm{SO}_{2}$ emissions are reduced by $30 \%$

Same as BASE_EMIS

$\mathrm{NO}_{\mathrm{x}}$ emissions are reduced by $30 \%$

Same as BASE_EMIS

$\mathrm{NH}_{3}$ emissions are reduced by $30 \%$

Same as BASE_EMIS

VOCs emissions are reduced by $30 \%$

Same as BASE_EMIS

Emissions of $\mathrm{SO}_{2}, \mathrm{NO}_{\mathrm{X}}$, and $\mathrm{NH}_{3}$ are reduced by $30 \%$ simutaneously

Same as BASE_EMIS

Emissions of $\mathrm{SO}_{2}, \mathrm{NO}_{\mathrm{X}}, \mathrm{NH}_{3}$, and VOCs are reduced by $30 \%$

simutaneously

Same as BASE_EMIS 
Table 2. Domainwide statistics of chemical predictions at a 36-km grid resolution over Domain 1.

\begin{tabular}{|c|c|c|c|c|c|c|c|c|c|}
\hline Concentrations & Simulation name & $\mathrm{n}$ & Obs. & Sim. & MB & $\begin{array}{l}\text { NMB } \\
(\%)\end{array}$ & $\begin{array}{l}\text { NME } \\
(\%)\end{array}$ & $\begin{array}{l}\text { MFB } \\
(\%)\end{array}$ & $\begin{array}{l}\text { MFE } \\
(\%)\end{array}$ \\
\hline \multirow{11}{*}{$\mathrm{PM}_{2.5}\left(\mu \mathrm{g} \mathrm{m}^{-3}\right)$} & BASE & & & 201.5 & 64.2 & 47 & 77 & 28 & 60 \\
\hline & RAD & & & 195.2 & 57.9 & 42 & 74 & 26 & 59 \\
\hline & MP & & & 186.6 & 49.4 & 36 & 69 & 22 & 57 \\
\hline & CU_GD & & & 201.0 & 63.8 & 46 & 77 & 28 & 60 \\
\hline & CU_KF & & & 203.0 & 65.8 & 48 & 78 & 29 & 60 \\
\hline & RAD_MP_KF & 61071 & 137.2 & 182.5 & 45.3 & 33 & 67 & 21 & 56 \\
\hline & RAD_MP_KF_Q & & & 179.4 & 42.2 & 31 & 66 & 20 & 56 \\
\hline & RAD_MP_KF_TRI & & & 183.4 & 46.1 & 34 & 68 & 21 & 57 \\
\hline & RAD_WDM6_KF & & & 194.6 & 57.3 & 42 & 72 & 27 & 58 \\
\hline & PX_RAD_MP_KF_351 & & & 177.9 & 40.7 & 30 & 67 & 18 & 57 \\
\hline & PX_RAD_MP_KF_Q_351 & & & 175.1 & 37.8 & 28 & 66 & 16 & 57 \\
\hline \multirow[t]{11}{*}{$\mathrm{PM}_{10}\left(\mu \mathrm{g} \mathrm{m}^{-3}\right)$} & BASE & & & 208.8 & 13.8 & 7 & 54 & 1 & 52 \\
\hline & RAD & & & 202.5 & 7.5 & 4 & 52 & 1 & 52 \\
\hline & $\mathrm{MP}$ & & & 194.8 & 0.2 & 0 & 51 & 5 & 52 \\
\hline & CU_GD & & & 208.4 & 13.3 & 7 & 54 & 1 & 52 \\
\hline & CU_KF & & & 210.5 & 15.5 & 8 & 54 & 2 & 52 \\
\hline & RAD_MP_KF & 55763 & 195.0 & 190.5 & 4.6 & 2 & 50 & 5 & 51 \\
\hline & RAD_MP_KF_Q & & & 187.1 & 7.9 & 4 & 49 & 7 & 51 \\
\hline & RAD_MP_KF_TRI & & & 191.5 & 3.6 & 2 & 50 & 5 & 51 \\
\hline & RAD_WDM6_KF & & & 195.4 & 0.3 & 0 & 52 & 6 & 53 \\
\hline & PX_RAD_MP_KF_351 & & & 181.6 & 13.4 & 7 & 52 & 11 & 54 \\
\hline & PX_RAD_MP_KF_Q_351 & & & 178.6 & 16.5 & 8 & 52 & 13 & 54 \\
\hline \multirow[t]{11}{*}{$\mathrm{SO}_{2}\left(\mu \mathrm{g} \mathrm{m}^{-3}\right)$} & BASE & & & 129.4 & 54.5 & 73 & 123 & 28 & 82 \\
\hline & RAD & & & 124.2 & 49.4 & 66 & 119 & 25 & 82 \\
\hline & $\mathrm{MP}$ & & & 107.9 & 33.1 & 44 & 106 & 8 & 82 \\
\hline & CU_GD & & & 129.2 & 54.4 & 73 & 123 & 28 & 82 \\
\hline & CU_KF & & & 129.9 & 55.1 & 74 & 123 & 28 & 82 \\
\hline & RAD_MP_KF & 61208 & 74.8 & 103.9 & 29.1 & 39 & 105 & 5 & 83 \\
\hline & RAD_MP_KF_Q & & & 99.4 & 24.6 & 33 & 101 & 2 & 82 \\
\hline & RAD_MP_KF_TRI & & & 104.3 & 29.5 & 39 & 105 & 5 & 83 \\
\hline & RAD_WDM6_KF & & & 120.2 & 45.4 & 61 & 115 & 22 & 81 \\
\hline & PX_RAD_MP_KF_351 & & & 143.1 & 68.3 & 91 & 147 & 21 & 88 \\
\hline & PX_RAD_MP_KF_Q_351 & & & 139.8 & 65.0 & 87 & 144 & 19 & 88 \\
\hline \multirow[t]{11}{*}{$\mathrm{NO}_{2}\left(\mu \mathrm{g} \mathrm{m}^{-3}\right)$} & BASE & & & 80.2 & 16.7 & 26 & 67 & 3 & 66 \\
\hline & RAD & & & 77.3 & 13.8 & 22 & 64 & 0.3 & 65 \\
\hline & MP & & & 71.9 & 8.4 & 13 & 59 & 4.8 & 63 \\
\hline & CU_GD & & & 80.2 & 16.7 & 26 & 67 & 4 & 66 \\
\hline & CU_KF & & & 80.6 & 17.1 & 27 & 67 & 4 & 66 \\
\hline & RAD_MP_KF & 61076 & 63.5 & 70.2 & 6.7 & 11 & 57 & 6.3 & 63 \\
\hline & RAD_MP_KF_Q & & & 69.3 & 5.8 & 9 & 56 & 6.5 & 62 \\
\hline & RAD_MP_KF_TRI & & & 70.3 & 6.8 & 11 & 57 & 6.3 & 63 \\
\hline & RAD_WDM6_KF & & & 77.0 & 13.5 & 21 & 64 & 0.2 & 65 \\
\hline & PX_RAD_MP_KF_351 & & & 72.2 & 8.7 & 14 & 57 & 1.2 & 61 \\
\hline & PX_RAD_MP_KF_Q_351 & & & 70.9 & 7.4 & 12 & 56 & 1.9 & 60 \\
\hline \multirow[t]{11}{*}{$\mathrm{CO}\left(\mathrm{mg} \mathrm{m}^{-3}\right)$} & BASE & & & 2.5 & 0.3 & 12 & 64 & -1.8 & 61 \\
\hline & RAD & & & 2.4 & 0.2 & 7 & 62 & -4.8 & 60 \\
\hline & MP & & & 2.4 & 0.1 & 5 & 61 & -6.1 & 60 \\
\hline & CU_GD & & & 2.5 & 0.3 & 11 & 64 & -1.7 & 61 \\
\hline & CU_KF & & & 2.6 & 0.3 & 12 & 64 & -1.0 & 61 \\
\hline & RAD_MP_KF & 61529 & 2.3 & 2.3 & 0.0 & 2 & 59 & -7.7 & 60 \\
\hline & RAD_MP_KF_Q & & & 2.3 & 0.0 & 1 & 59 & -8.4 & 59 \\
\hline & RAD_MP_KF_TRI & & & 2.3 & 0.1 & 2 & 60 & -7.6 & 60 \\
\hline & RAD_WDM6_KF & & & 2.4 & 0.1 & 5 & 61 & -5.3 & 60 \\
\hline & PX_RAD_MP_KF_351 & & & 2.5 & 0.2 & 11 & 66 & -3.8 & 62 \\
\hline & PX_RAD_MP_KF_Q_351 & & & 2.5 & 0.2 & 10 & 66 & -4.1 & 62 \\
\hline
\end{tabular}


814 Table 3. Comparison of model performance on meteorological predictions of the RAD_MP_KF_Q and the

815 BASE simulations in terms of NMB over Domain 1 at 36-km grid resolution, and Domain 2 at 36- and 12$816 \mathrm{~km}$ grid resolutions.

\begin{tabular}{c|cc|ccc}
\hline NMB (\%) & \multicolumn{2}{|c|}{ East Asia (Domain 1) } & \multicolumn{3}{c}{ Northern China (Domain 2) } \\
Simulation Name & BASE & RAD_MP_KF_Q & BASE & $\begin{array}{c}\text { RAD_MP_KF_Q } \\
(36-k m)\end{array}$ & $\begin{array}{c}\text { RAD_MP_KF_Q } \\
(\text { 12-km) }\end{array}$ \\
\hline T2 & -77 & -61 & -55 & -46 & -33 \\
Q2 & 12 & 14 & 8 & 12 & 11 \\
WS10 & 33 & 35 & 1 & 4 & 5 \\
WD10 & 2 & 2 & -0.2 & 0.1 & -0.4 \\
Precipitation & -76 & -3 & -82 & -19 & -21 \\
\hline
\end{tabular}


818 Table 4. Domainwide statistics of chemical predictions over Domain 2 at 36- and 12-km grid resolutions

\begin{tabular}{|c|c|c|c|c|c|c|c|c|c|c|}
\hline Concentrations & Simulation name & Resolution $(\mathrm{km})$ & $\mathrm{n}$ & Obs. & Sim. & MB & NMB $(\%)$ & NME $(\%)$ & MFB (\%) & $\operatorname{MFE}(\%)$ \\
\hline \multirow{12}{*}{$\mathrm{PM}_{2.5}\left(\mu \mathrm{g} \mathrm{m}^{-3}\right)$} & BASE & 36 & \multirow{12}{*}{50433} & \multirow{12}{*}{155.3} & 263.8 & 108.5 & 70 & 89 & 48 & 64 \\
\hline & RAD & 36 & & & 255.5 & 100.2 & 65 & 84 & 45 & 62 \\
\hline & MP & 36 & & & 244.8 & 89.5 & 58 & 79 & 42 & 60 \\
\hline & CU_GD & 36 & & & 262.9 & 107.5 & 69 & 88 & 48 & 64 \\
\hline & CU_KF & 36 & & & 264.9 & 109.6 & 71 & 89 & 48 & 64 \\
\hline & RAD_MP_KF & 36 & & & 236.6 & 81.3 & 52 & 75 & 40 & 59 \\
\hline & RAD_MP_KF_TRI & 36 & & & 238.0 & 82.7 & 53 & 75 & 40 & 59 \\
\hline & RAD_WDM6_KF & 36 & & & 252.4 & 97.1 & 62 & 82 & 45 & 61 \\
\hline & PX_RAD_MP_KF_351 & 36 & & & 227.9 & 72.5 & 47 & 73 & 35 & 58 \\
\hline & PX_RAD_MP_KF_Q_351 & 36 & & & 226.0 & 70.7 & 46 & 72 & 34 & 58 \\
\hline & RAD_MP_KF_Q & 36 & & & 233.5 & 78.2 & 50 & 73 & 39 & 58 \\
\hline & RAD_MP_KF_Q & 12 & & & 225.7 & 70.4 & 45 & 79 & 23 & 63 \\
\hline \multirow[t]{12}{*}{$\mathrm{PM}_{10}\left(\mu \mathrm{g} \mathrm{m}^{-3}\right)$} & BASE & 36 & \multirow{12}{*}{43519} & \multirow{12}{*}{222.1} & 271.9 & 49.8 & 22 & 55 & 19 & 51 \\
\hline & RAD & 36 & & & 263.9 & 41.7 & 19 & 53 & 17 & 50 \\
\hline & MP & 36 & & & 254.0 & 31.8 & 14 & 50 & 14 & 49 \\
\hline & CU_GD & 36 & & & 270.9 & 48.7 & 22 & 55 & 19 & 51 \\
\hline & CU_KF & 36 & & & 272.9 & 50.8 & 23 & 55 & 20 & 51 \\
\hline & RAD__MP_KF & 36 & & & 245.7 & 23.6 & 11 & 49 & 11 & 48 \\
\hline & RAD_MP_KF_TRI & 36 & & & 247.1 & 25.0 & 11 & 50 & 12 & 49 \\
\hline & RAD_WDM6_KF & 36 & & & 262.1 & 40.0 & 18 & 52 & 17 & 49 \\
\hline & PX_RAD_MP_KF_351 & 36 & & & 231.6 & 9.4 & 4 & 51 & 4 & 51 \\
\hline & PX_RAD_MP_KF_Q_351 & 36 & & & 229.4 & 7.3 & 3 & 51 & 3 & 51 \\
\hline & RAD_MP_KF_Q & 36 & & & 241.9 & 19.7 & 9 & 48 & 10 & 48 \\
\hline & RAD_MP_KF_Q & 12 & & & 231.7 & 9.6 & 4 & 56 & -6 & 56 \\
\hline \multirow{12}{*}{$\mathrm{SO}_{2}\left(\mu \mathrm{g} \mathrm{m}^{-3}\right)$} & BASE & 36 & \multirow{12}{*}{50390} & \multirow{12}{*}{99.2} & 167.4 & 68.2 & 69 & 110 & 45 & 82 \\
\hline & RAD & 36 & & & 161.5 & 62.3 & 63 & 106 & 42 & 81 \\
\hline & MP & 36 & & & 145.3 & 46.1 & 46 & 97 & 30 & 78 \\
\hline & CU_GD & 36 & & & 167.1 & 67.9 & 68 & 110 & 45 & 82 \\
\hline & CU_KF & 36 & & & 168.1 & 68.9 & 69 & 110 & 45 & 82 \\
\hline & RAD_MP_KF & 36 & & & 138.1 & 38.8 & 39 & 94 & 26 & 77 \\
\hline & RAD_MP_KF_TRI & 36 & & & 138.8 & 39.6 & 40 & 95 & 26 & 78 \\
\hline & RAD_WDM6_KF & 36 & & & 155.1 & 55.8 & 56 & 102 & 39 & 79 \\
\hline & PX_RAD_MP_KF_351 & 36 & & & 181.2 & 82.0 & 83 & 128 & 41 & 85 \\
\hline & PX_RAD_MP_KF_Q_351 & 36 & & & 175.3 & 76.1 & 77 & 124 & 38 & 84 \\
\hline & RAD_MP_KF_Q & 36 & & & 131.2 & 32.0 & 32 & 89 & 22 & 76 \\
\hline & RAD_MP_KF_Q & 12 & & & 212.6 & 113.4 & 114 & 165 & 30 & 93 \\
\hline \multirow[t]{12}{*}{$\mathrm{NO}_{2}\left(\mu \mathrm{g} \mathrm{m}^{-3}\right)$} & BASE & 36 & \multirow{12}{*}{50442} & \multirow{12}{*}{63.5} & 105.6 & 40.0 & 61 & 78 & 40 & 62 \\
\hline & RAD & 36 & & & 101.6 & 36.0 & 55 & 73 & 38 & 60 \\
\hline & MP & 36 & & & 93.8 & 28.2 & 43 & 65 & 31 & 57 \\
\hline & CU_GD & 36 & & & 105.5 & 39.9 & 61 & 78 & 40 & 62 \\
\hline & CU_KF & 36 & & & 105.8 & 40.2 & 61 & 78 & 41 & 62 \\
\hline & RAD_MP_KF & 36 & & & 90.6 & 25.0 & 38 & 62 & 28 & 55 \\
\hline & RAD_MP_KF_TRI & 36 & & & 90.9 & 25.3 & 39 & 62 & 29 & 55 \\
\hline & RAD_WDM6_KF & 36 & & & 101.1 & 35.5 & 54 & 72 & 38 & 59 \\
\hline & PX_RAD_MP_KF_351 & 36 & & & 90.9 & 25.3 & 39 & 63 & 29 & 55 \\
\hline & PX_RAD_MP_KF_Q_351 & 36 & & & 89.3 & 23.7 & 36 & 61 & 27 & 55 \\
\hline & RAD_MP_KF_Q & 36 & & & 89.4 & 23.8 & 36 & 60 & 27 & 55 \\
\hline & RAD_MP_KF_Q & 12 & & & 91.8 & 26.2 & 40 & 75 & 12 & 64 \\
\hline \multirow[t]{12}{*}{$\mathrm{CO}\left(\mathrm{mg} \mathrm{m}^{-3}\right)$} & BASE & 36 & & & 3.6 & 0.9 & 32 & 66 & 25 & 59 \\
\hline & RAD & 36 & & & 3.4 & 0.7 & 26 & 64 & 22 & 58 \\
\hline & MP & 36 & & & 3.4 & 0.7 & 25 & 62 & 21 & 57 \\
\hline & CU_GD & 36 & & & 3.5 & 0.8 & 30 & 74 & 22 & 67 \\
\hline & CU_KF & 36 & & & 3.6 & 0.9 & 32 & 67 & 26 & 59 \\
\hline & RAD_MP_KF & 36 & 50584 & 2.7 & 3.2 & 0.5 & 19 & 59 & 17 & 56 \\
\hline & RAD_MP_KF_TRI & 36 & & & 3.2 & 0.5 & 20 & 59 & 18 & 56 \\
\hline & RAD_WDM6_KF & 36 & & & 3.3 & 0.6 & 22 & 69 & 18 & 64 \\
\hline & PX_RAD_MP_KF_351 & 36 & & & 3.5 & 0.8 & 28 & 67 & 21 & 60 \\
\hline & PX_RAD_MP_KF_Q_351 & 36 & & & 3.5 & 0.8 & 29 & 69 & 21 & 60 \\
\hline & RAD_MP_KF_Q & 36 & & & 3.2 & 0.5 & 18 & 58 & 16 & 55 \\
\hline & RAD_MP_KF_Q & 12 & & & 3.7 & 1.0 & 36 & 81 & 10 & 65 \\
\hline
\end{tabular}


822 Table 5. Comparison of model performance on air quality predictions of the RAD_MP_KF_Q and the

823 BASE simulations in terms of NMB over Domain 1 at 36-km grid resolution, and Domain 2 at 36- and 12-

$824 \mathrm{~km}$ grid resolutions.

\begin{tabular}{c|cc|ccc}
\hline NMB $(\%)$ & \multicolumn{2}{|c|}{ East Asia (Domain 1) } & \multicolumn{3}{c}{ Northern China (Domain 2) } \\
Simulation Name & BASE & RAD_MP_KF_Q & $\begin{array}{c}\text { BASE } \\
\text { RAD_MP_KF_Q }\end{array}$ & $\begin{array}{c}\text { RA_Kr_km) } \\
\text { RAD_MP_KF_Q } \\
(\text { (12-km) }\end{array}$ \\
\hline $\mathrm{PM}_{2.5}$ & 47 & 31 & 70 & 50 & 45 \\
$\mathrm{PM}_{10}$ & 7 & 4 & 22 & 9 & 4 \\
$\mathrm{SO}_{2}$ & 73 & 33 & 69 & 32 & 114 \\
$\mathrm{NO}_{2}$ & 26 & 9 & 61 & 36 & 40 \\
$\mathrm{CO}$ & 12 & 1 & 32 & 18 & 36 \\
\hline
\end{tabular}


826 Figure 1. WRF/Chem modeling domains at a horizontal grid resolution of 36-km over East Asia 827 (Domain 1 with $164 \times 97$ cells) and 12-km over an area in northern China (Domain 2 with $90 \times$ $828 \quad 108$ cells).

829 Figure 2. Overlay of the simulated (RAD_MP_KF_Q) and observed monthly average concentrations 830 of $\mathrm{PM}_{2.5}, \mathrm{PM}_{10}, \mathrm{SO}_{2}, \mathrm{NO}_{2}$, and $\mathrm{CO}$ (a) and their NMBs (b) over the Domain 1 at 36-km grid 831 resolution.

832 Figure 3. Overlay of the simulated (RAD_MP_KF_Q) and observed monthly average concentrations 833 of $\mathrm{PM}_{2.5}, \mathrm{PM}_{10}, \mathrm{SO}_{2}, \mathrm{NO}_{2}$, and $\mathrm{CO}$, and their $\mathrm{NMBs}$ over the Domain 2 at 36- and 12-km grid 834 resolutions ((a) and (b), respectively), and NMBs at 36- and 12-km grid resolutions ((c) and (d), 835 respectively).

836 Figure 4. $\mathrm{PM}_{2.5}$ concentrations and the sensitivities to the emission changes of $\mathrm{SO}_{2}, \mathrm{NO}_{\mathrm{x}}, \mathrm{NH}_{3}$, and 837 VOCs over the Domain 1 by RAD_MP_KF_Q simulation (emission reduction simulation 838 BASE_EMIS). (a) The predicted baseline $\mathrm{PM}_{2.5}$ concentrations. Change in $\mathrm{PM}_{2.5}$ concentrations 839 and percentages when (b) $\mathrm{SO}_{2}$ emissions are reduced by $30 \%$. (c) $\mathrm{NO}_{\mathrm{x}}$ emissions are reduced by $84030 \%$. (d) $\mathrm{NH}_{3}$ emissions are reduced by $30 \%$. (e) VOCs emissions are reduced by $30 \%$. (f) $\mathrm{SO}_{2}$, $841 \mathrm{NO}_{\mathrm{x}}$, and $\mathrm{NH}_{3}$ emissions are reduced by $30 \%$ simutaneously. (g) $\mathrm{SO}_{2}, \mathrm{NO}_{\mathrm{x}}, \mathrm{NH}_{3}$, and VOCs 842 emissions are reduced by $30 \%$ simutaneously.

843 Figure 5. Spatial distribution of the simulated (RAD_MP_KF_Q) and satellite observed monthly 844 mean column mass abundances of $\mathrm{HCHO}, \mathrm{NO}_{2}$ and $\mathrm{HCHO} / \mathrm{NO}_{2}$ over Domain 1. 


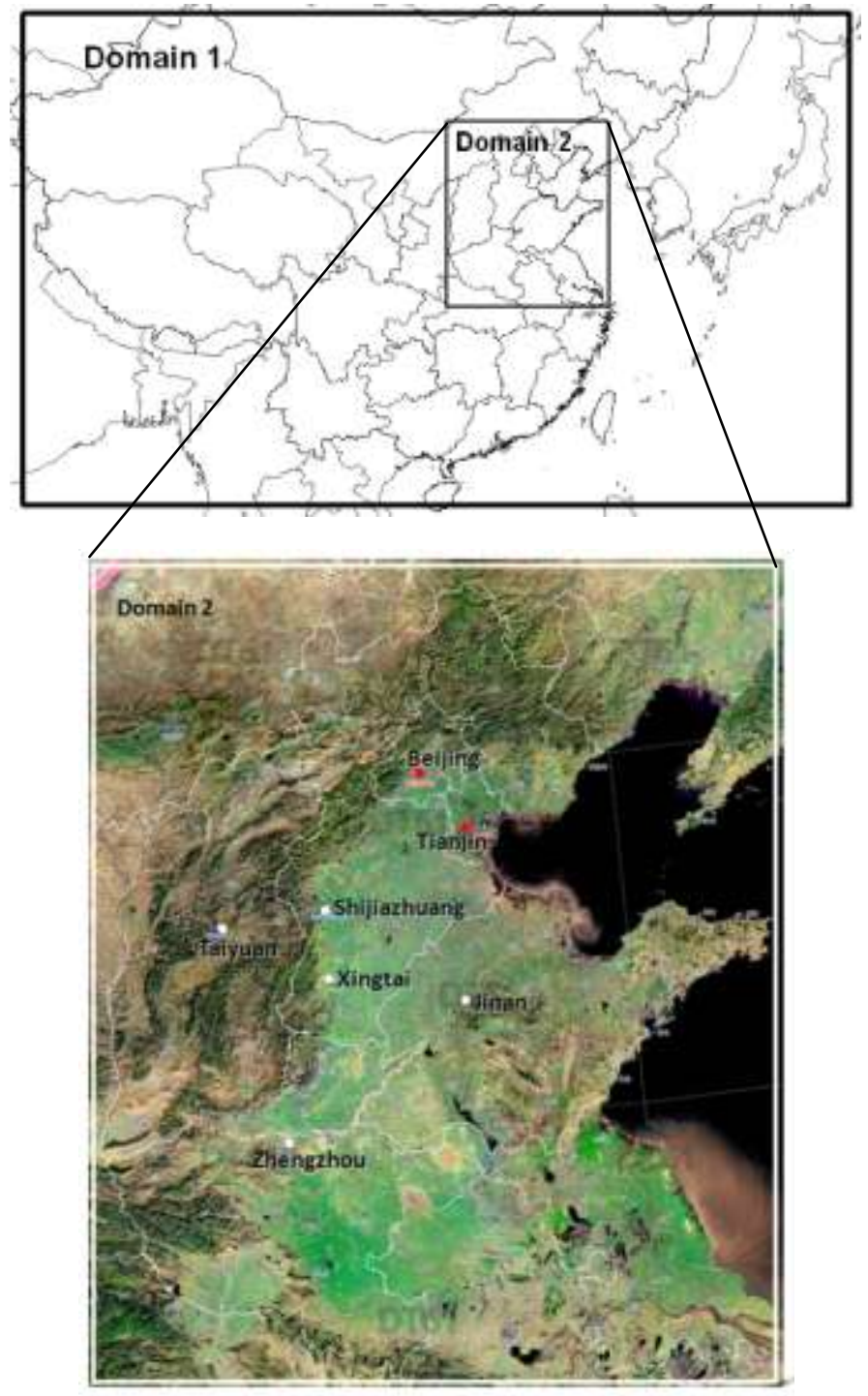

Figure 1. WRF/Chem modeling domains at a horizontal grid resolution of 36-km over East

847 Asia (Domain 1 with $164 \times 97$ cells) and 12-km over an area in northern China (Domain 2 with $90 \times$ 848108 cells). 

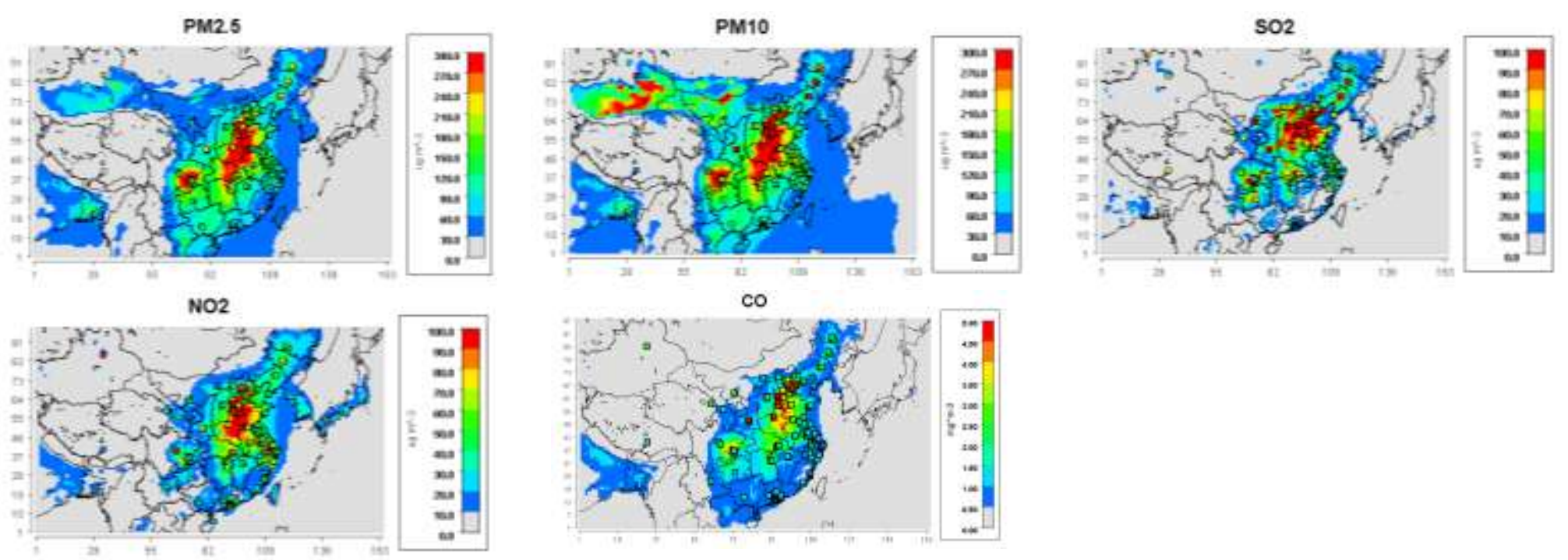

(a) overlay of the simulated and observed concentrations

PM25

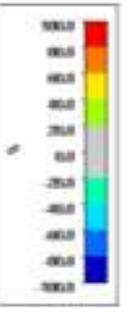

NO2
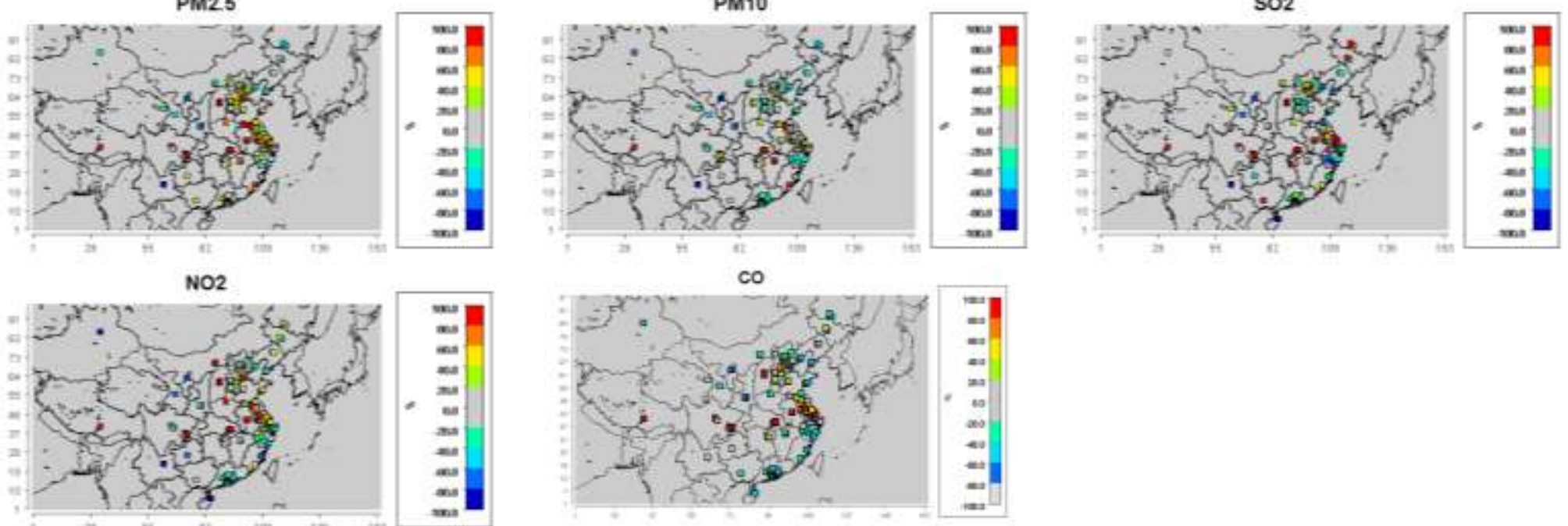

co

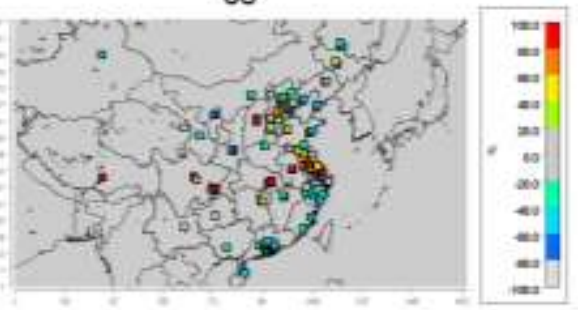

(b) NMBs

Figure 2. Overlay of the simulated (RAD_MP_KF_Q) and observed monthly average concentrations of $\mathrm{PM}_{2.5}, \mathrm{PM}_{10}, \mathrm{SO}_{2}, \mathrm{NO}_{2}$, and CO (a) and their NMBs (b) over the Domain 1 at 36-km grid resolution. 

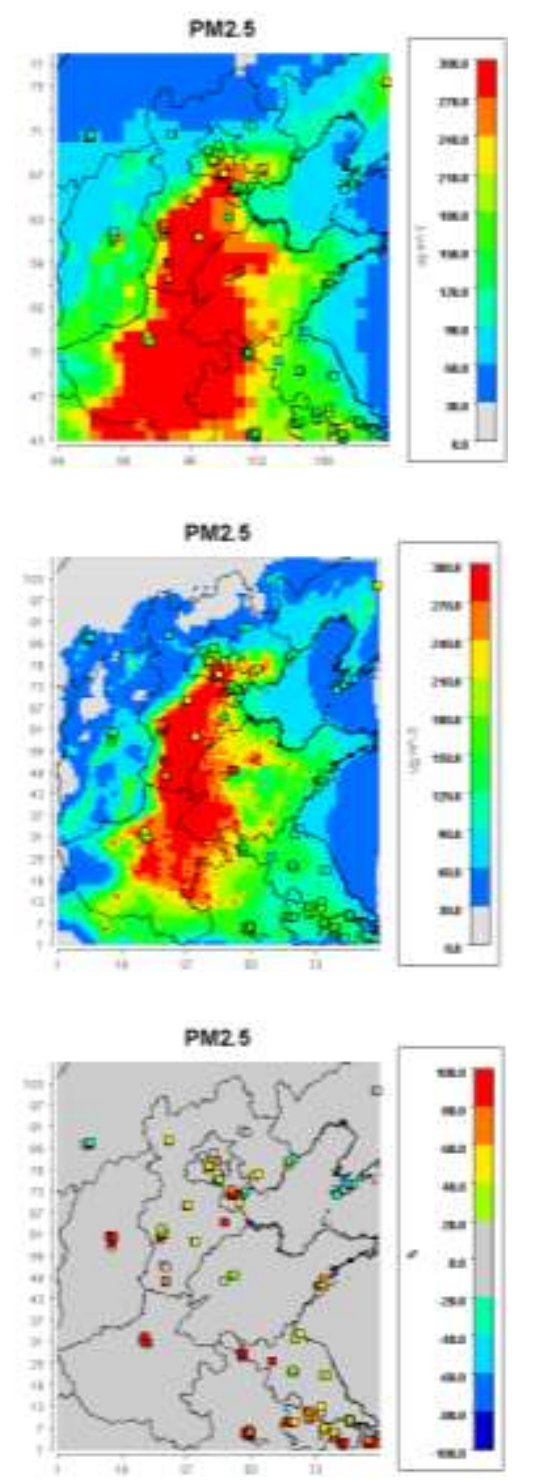
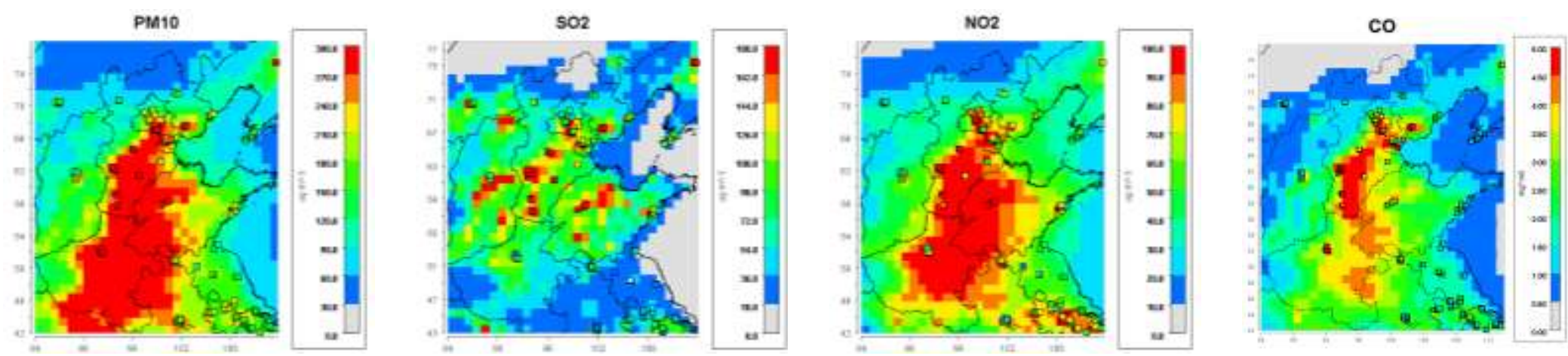

(a) Concentration overlay at a $36-\mathrm{km}$ grid resolution
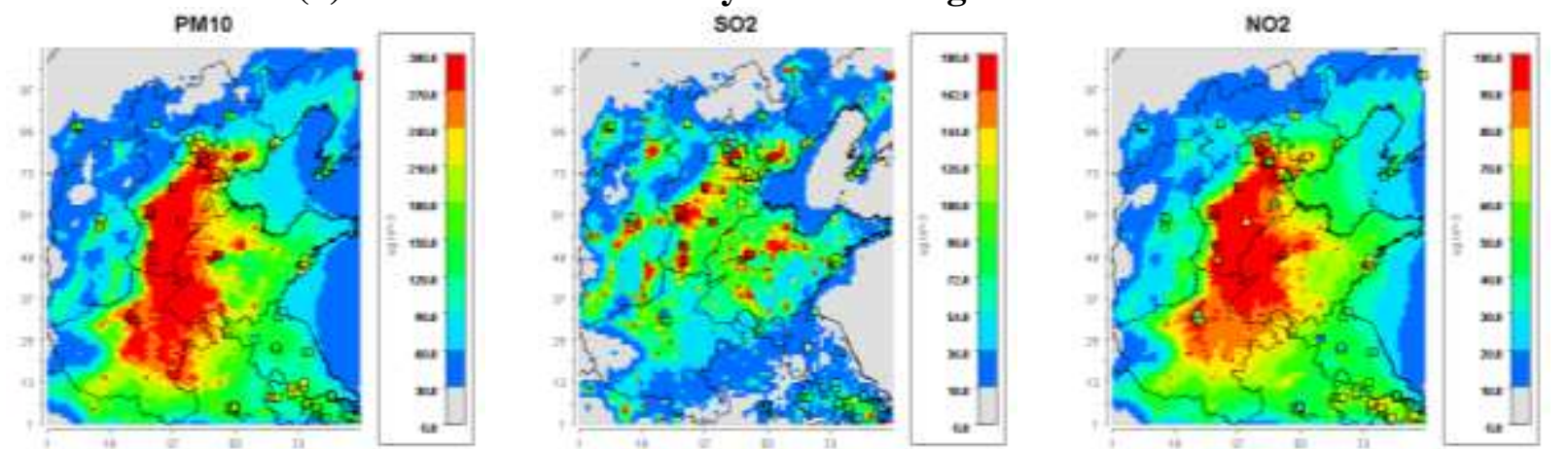

(b) Concentration overlay at a 12-km grid resolution
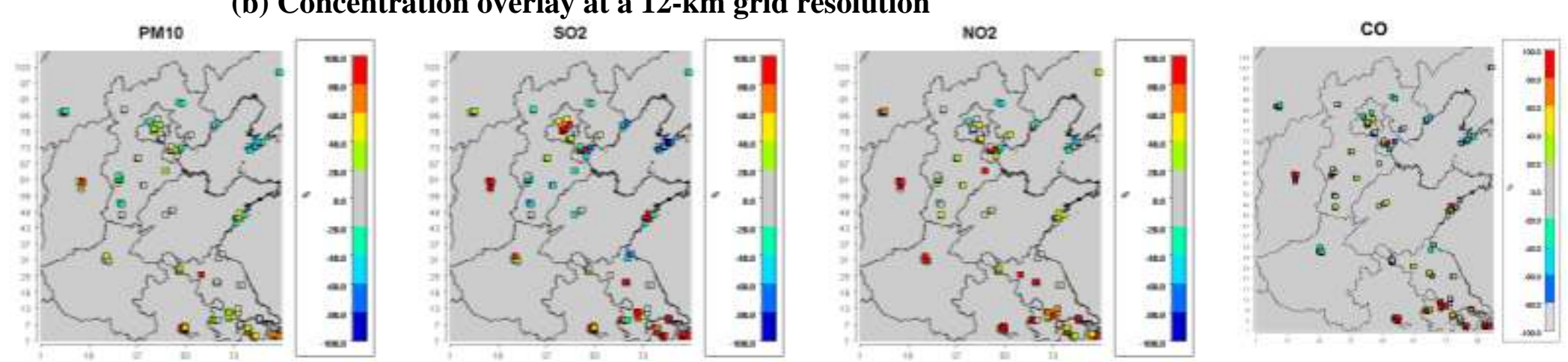

(c) NMBs at a 36-km grid resolution

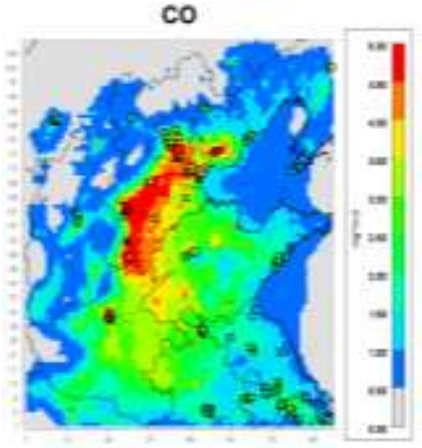



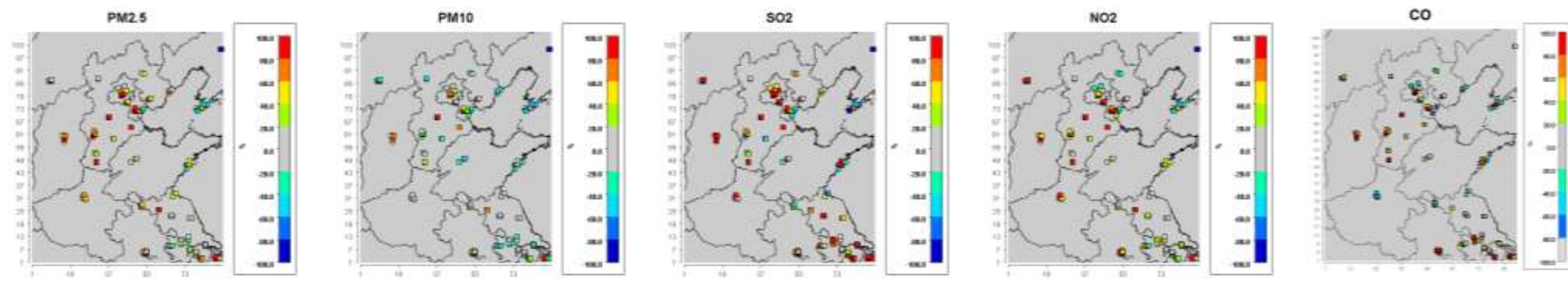

(d) NMBs at a 12-km grid resolution

Figure 3. Overlay of the simulated (RAD_MP_KF_Q) and observed monthly average concentrations of $\mathrm{PM}_{2.5}, \mathrm{PM}_{10}, \mathrm{SO}_{2}, \mathrm{NO}_{2}$, and $\mathrm{CO}$, and their

852 NMBs over the Domain 2 at 36- and 12-km grid resolutions ((a) and (b), respectively), and NMBs at 36- and 12-km grid resolutions ((c) and (d),

respectively). 


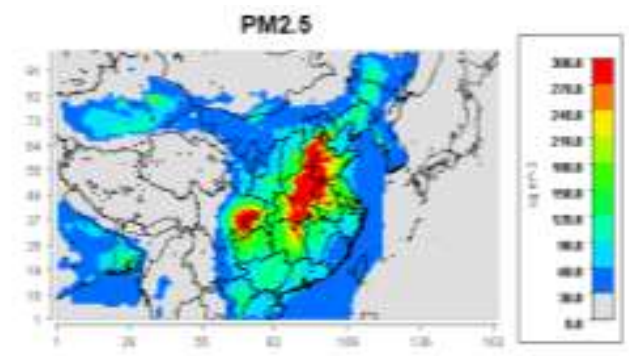

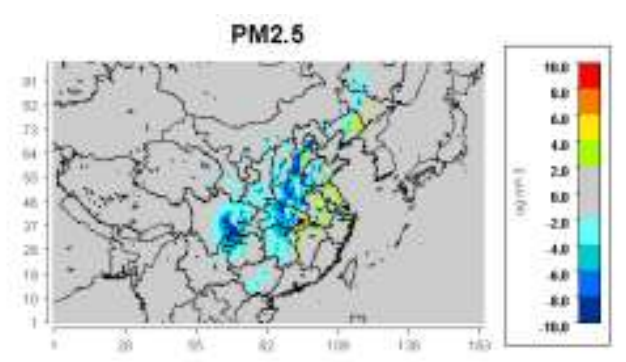

(b) $\mathrm{SO}_{2 \_} 30$

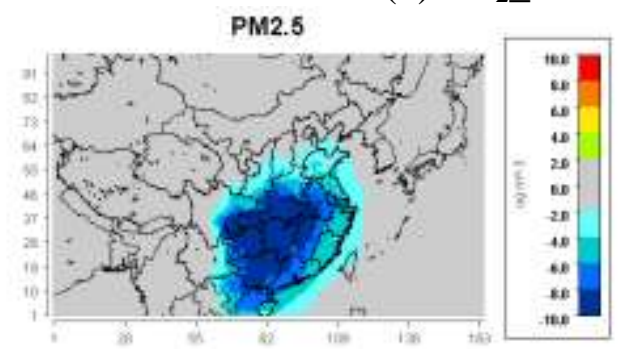

(d) $\mathrm{NH}_{3} \_30$

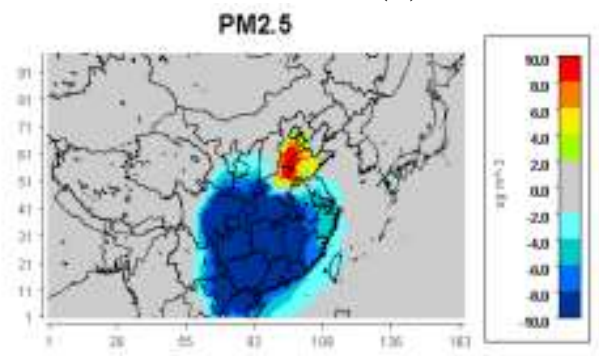

(f) $\mathrm{SO}_{2} \_\mathrm{NO}_{\mathrm{X}} \_\mathrm{NH}_{3} \_30$ (a) BASE_EMIS (RAD_MP_KF_Q)
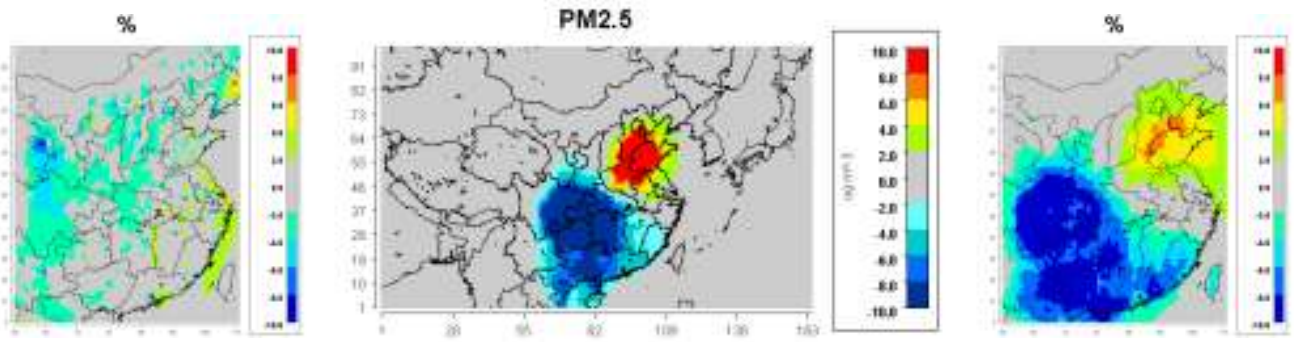

(c) $\mathrm{NO}_{\mathrm{X} \_} 30$
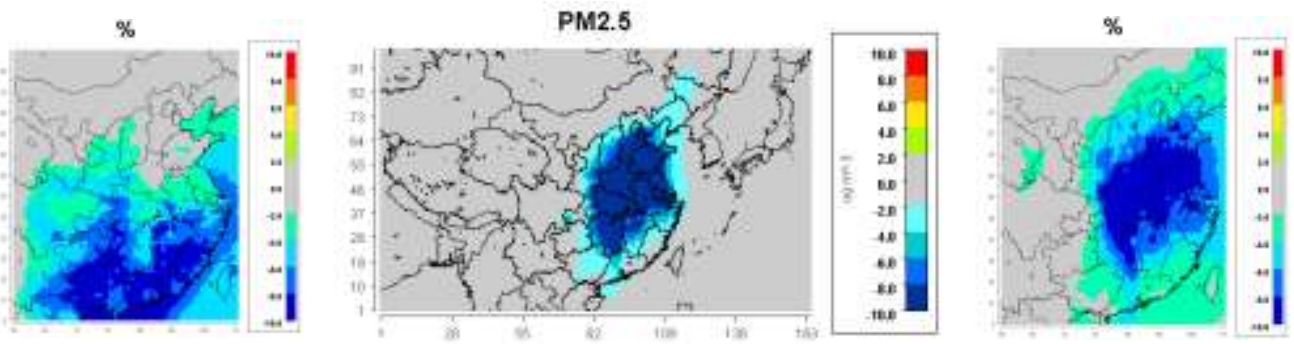

(e) VOCs_30
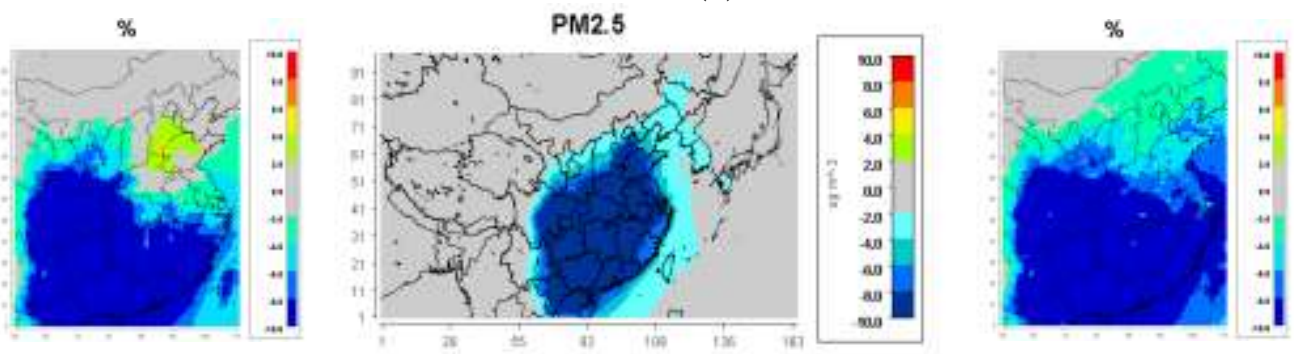

(g) $\mathrm{SO}_{2} \_\mathrm{NO}_{\mathrm{X} \_} \mathrm{NH}_{3} \_\mathrm{VOCs} \_30$

Figure 4. $\mathrm{PM}_{2.5}$ concentrations and the sensitivities to the emission changes of $\mathrm{SO}_{2}, \mathrm{NO}_{\mathrm{x}}, \mathrm{NH}_{3}$, and

856 VOCs over the Domain 1 by RAD_MP_KF_Q simulation (emission reduction simulation - BASE_EMIS).

(a) The predicted baseline $\mathrm{PM}_{2.5}$ concentrations. Change in $\mathrm{PM}_{2.5}$ concentrations and percentages when (b) by $30 \%$. (e) VOCs emissions are reduced by $30 \%$. (f) $\mathrm{SO}_{2}, \mathrm{NO}_{\mathrm{x}}$, and $\mathrm{NH}_{3}$ emissions are reduced by $30 \%$

860 simutaneously. (g) $\mathrm{SO}_{2}, \mathrm{NO}_{\mathrm{x}}, \mathrm{NH}_{3}$, and VOCs emissions are reduced by $30 \%$ simutaneously. 


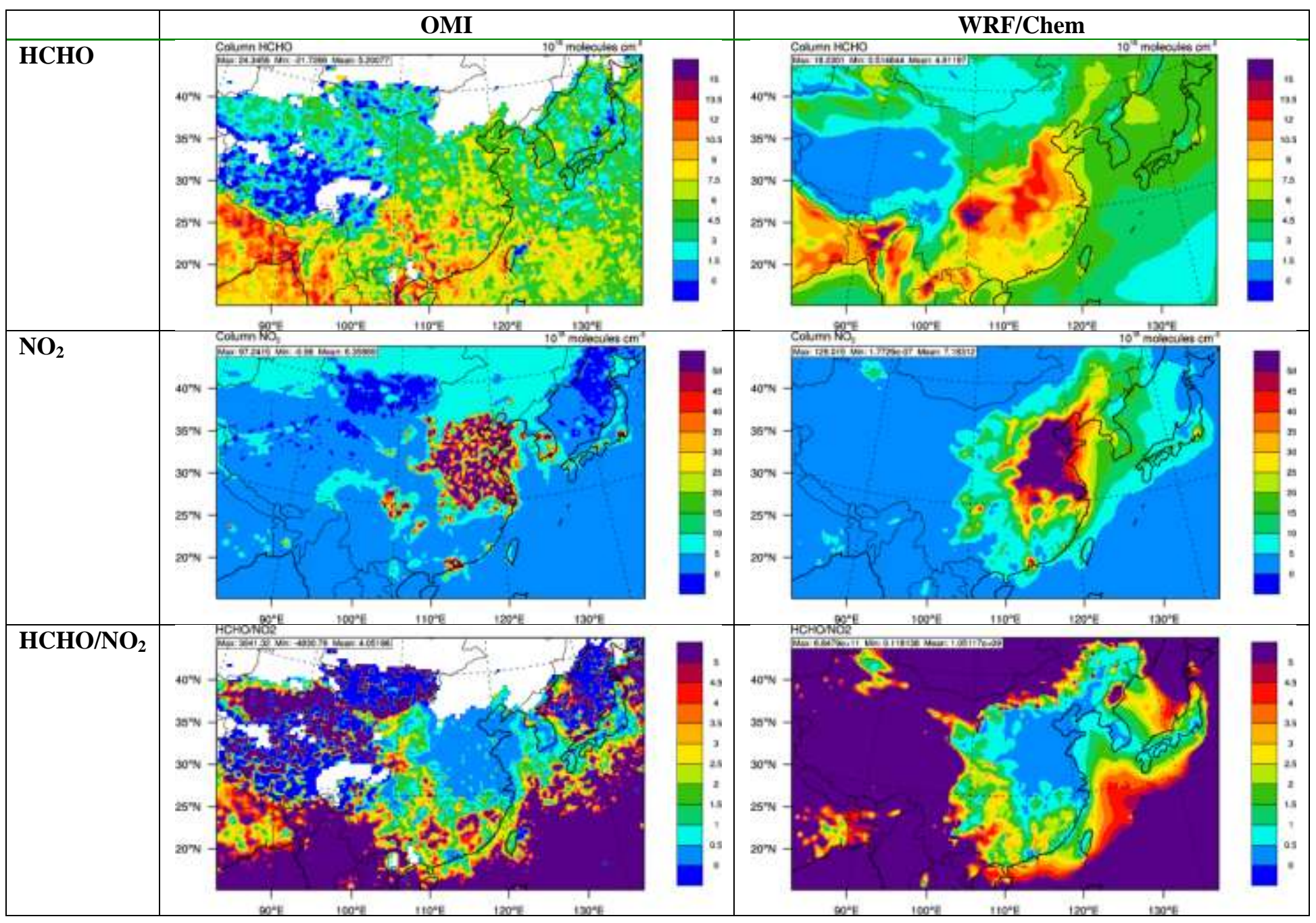

Figure 5. Spatial distribution of the simulated (RAD_MP_KF_Q) and satellite observed monthly mean

864 column mass abundances of $\mathrm{HCHO}, \mathrm{NO}_{2}$ and $\mathrm{HCHO} / \mathrm{NO}_{2}$ over Domain 1. 